Supporting Information

\title{
Ordered PdCu-based Core-Shell Concave Nanocubes Enclosed by High-Index Facets for Ethanol Electrooxidation
}

Genlei Zhang, , \#, a Yan Shi, ${ }^{\#, a}$ Yan Fang, ${ }^{a}$ Dongjie Cao, ${ }^{a}$ Shiyu Guo, ${ }^{a}$ Qi Wang, ${ }^{a}$ Yazhong Chen, ${ }^{a}$ Peng Cui, ${ }^{a}$ Sheng Cheng ${ }^{b}$

${ }^{a}$ School of Chemistry and Chemical Engineering, Anhui Province Key Laboratory of Advanced Catalytic Materials and Reaction Engineering, Anhui Province Key Laboratory of Controllable Chemistry Reaction and Material Chemical Engineering, Hefei University of Technology, Hefei, 230009, PR China

${ }^{\mathrm{b}}$ School of Chemistry and Chemical Engineering, Hefei University of Technology, Hefei, 230009, PR China

\# These authors contributed equally to this work

*Corresponding E-mail: genleizhang@hfut.edu.cn 


\section{Experimental section}

\section{Materials}

Platinum acetylacetonate $\left(\mathrm{Pt}(\mathrm{acac})_{2}\right)$, copper acetylacetonate $\left(\mathrm{Cu}(\mathrm{acac})_{2}\right)$, hydrogen tetrachloroaurate (III) trihydrate $\left(\mathrm{HAuCl}_{4} \cdot 3 \mathrm{H}_{2} \mathrm{O}\right)$, sodium chloroplatinate $\left(\mathrm{Na}_{2} \mathrm{PdCl}_{4}\right)$, hexadecyltrimethylammonium bromide $(\mathrm{CTAB})$, oleylamine $(\mathrm{OAm})$, anhydrous ethanol $\left(\mathrm{C}_{2} \mathrm{H}_{5} \mathrm{OH}\right)$, sodium hydroxide $(\mathrm{NaOH})$ were purchased from Sinopharm Chemical Reagent Co. Ltd., China. Phloroglucinol (PG), ascorbic acid (AA), sodium borohydride $\left(\mathrm{NaBH}_{4}\right)$, glucose $\left(\mathrm{C}_{6} \mathrm{H}_{12} \mathrm{O}_{6}\right)$ and Iron (III) chloride hexahydrate $\left(\mathrm{FeCl}_{3} \cdot 6 \mathrm{H}_{2} \mathrm{O}\right)$ were purchased from Aladdin. The commercial palladium black (Pd black) was purchased from Alfa Aesar. Carbon black (Vulcan XC-72) and the Nafion solution ( $5 \mathrm{wt} \%$ ) were purchased from Hesen electric Co. Ltd., China. All the chemicals were used as received without further purification. The deionized (DI) water used in all experiments was prepared by passing through an ultra-pure purification system, and all aqueous solutions were prepared using the DI water. High purity nitrogen $\left(\mathrm{N}_{2}, \geq 99.99 \%\right)$ and carbon monoxide $(\mathrm{CO}, \geq 99.99 \%)$ were supplied by Tianjin dongxiang Co. Ltd., China. Glassy carbon electrode $\left(0.07065 \mathrm{~cm}^{2}\right.$ in area) was purchased from Tianjin Aida Tech. Co. Ltd., China.

\section{Synthesis of Au seeds}

The Au seeds were prepared using a two-step procedure. ${ }^{[1]}$ Firstly, $0.5 \mathrm{~mL}$ of $10 \mathrm{mM} \mathrm{HAuCl} 4$ solution was mixed with $7.5 \mathrm{~mL}$ of $100 \mathrm{mM} \mathrm{CTAB}$ solution. Subsequently, $1 \mathrm{~mL}$ of $5 \mathrm{mM}$ ice-cooled $\mathrm{NaBH}_{4}$ solution was quickly injected into the above mixture to make the primary Au seeds. Secondly, $1 \mathrm{~mL}$ of $10 \mathrm{mM} \mathrm{HAuCl}_{4}, 1.6 \mathrm{~mL}$ of $100 \mathrm{mM} \mathrm{CTAB}$ and $6 \mathrm{~mL}$ of $50 \mathrm{mM} \mathrm{AA}$ aqueous solutions were mixed in a glass vial, followed by the addition of $0.1 \mathrm{~mL}$ of the primary seed solution. The final mixture turned from colorless to red within $1 \mathrm{~min}$, and after left undisturbed for $1 \mathrm{~h}$ at room temperature, the products were collected by centrifugation $(12000 \mathrm{rpm}, 10 \mathrm{~min})$ and then washed three times with ethanol to obtained Au seeds. 


\section{Synthesis of O-Pd ${ }_{1} \mathrm{Cu}$ Nanoparticles}

The synthetic strategy is the same as that of $\mathrm{Au} @ \mathrm{O}-\mathrm{Pd}_{1} \mathrm{Cu}$ CNCs without $\mathrm{Au}$ seeds. $9.2 \mathrm{mg}$ $\mathrm{Pd}(\mathrm{acac})_{2}, 7.9 \mathrm{mg} \mathrm{Cu}(\mathrm{acac})_{2}, 5.4 \mathrm{mg} \mathrm{FeCl}{ }_{3} \cdot 6 \mathrm{H}_{2} \mathrm{O}, 40 \mathrm{mg}$ PG and $100 \mathrm{mg}$ CTAB were simultaneously added into a $10 \mathrm{~mL}$ Teflon lining and further ultrasonicated for 60 minutes. The resulting homogeneous mixture was then heated at $180{ }^{\circ} \mathrm{C}$ for $12 \mathrm{~h}$ in a vacuum oven. The resulting ordered bcc $\mathrm{O}-\mathrm{Pd}_{1} \mathrm{Cu}$ alloy NPs were collected by centrifugation (12000 rpm, $10 \mathrm{~min})$ and washed three times with an ethanol/cyclohexane mixture, and then dried at $60{ }^{\circ} \mathrm{C}$ in an oven overnight.

\section{Synthesis of $\mathrm{Au} @ \mathrm{D}-\mathrm{Pd}_{1} \mathrm{Cu}$ nanocubes}

Firstly, $0.5 \mathrm{mg}$ Au seeds were re-dispersed in $10 \mathrm{~mL}$ water to form an $\mathrm{Au}$ seed suspension with an Au seed concentration of $50 \mathrm{mg} / \mathrm{L}$. Subsequently, $3 \mathrm{~mL}$ of $10 \mathrm{mM} \mathrm{Na}_{2} \mathrm{PdCl}_{4}, 1.2 \mathrm{~mL}$ of $50 \mathrm{mM} \mathrm{CuCl}_{2}$, and $1 \mathrm{~mL}$ of $50 \mathrm{mM}$ AA aqueous solutions were added to $4.8 \mathrm{~mL}$ of an aqueous solution containing 100 $\mathrm{mM}$ of $\mathrm{CTAB}$, followed by the addition of above $5 \mathrm{~mL}$ of $50 \mathrm{mg} / \mathrm{L} \mathrm{Au}$ seed suspension at room temperature. This mixed solution was placed in a $30 \mathrm{~mL}$ vial, which was capped and then heated at $80{ }^{\circ} \mathrm{C}$ in an oil bath under magnetic stirring for 1 h. The $\mathrm{Au} @ \mathrm{D}-\mathrm{Pd}{ }_{1} \mathrm{Cu}$ nanocubes $(\mathrm{NCs})$ were collected by centrifugation (12000 rpm, $10 \mathrm{~min})$, and then washed three times with water.

\section{Synthesis of D-Pd $1 \mathrm{Cu}$ nanocubes}

$3 \mathrm{~mL}$ of $10 \mathrm{mM} \mathrm{Na}_{2} \mathrm{PdCl}_{4}, 1.2 \mathrm{~mL}$ of $50 \mathrm{mM} \mathrm{CuCl}_{2}$, and $1 \mathrm{~mL}$ of $50 \mathrm{mM} \mathrm{AA}$ aqueous solutions were added to $4.8 \mathrm{~mL}$ of an aqueous solution containing $100 \mathrm{mM}$ of CTAB. This mixed solution was placed in a $30 \mathrm{~mL}$ vial, which was capped and then heated at $80{ }^{\circ} \mathrm{C}$ in an oil bath under magnetic stirring for $1 \mathrm{~h}$. The D-Pd $\mathrm{Cu}$ NCs were collected by centrifugation (12000 rpm, $10 \mathrm{~min})$, and then washed three times with water.

\section{Characterizations}

Transmission electron microscopy (TEM) and high-resolution TEM (HRTEM) were performed using JEOL 2100F microscope (JEOL; Japan) operated at $200 \mathrm{kV}$. High-angle annular dark field (HAADF) 
images and EDS elemental mapping analysis were carried out by using the scanning transmission electron microscopy (STEM) mode on an aberration corrected FEI Titan G2 60-300 field-emission TEM (FEI, USA), operated at $300 \mathrm{kV}\left(\alpha_{\max }=\sim 100 \mathrm{mrad}\right)$. Under these experimental conditions, the image contrast is related directly to the atomic number (Z-contrast). All the samples for TEM study were prepared by dropping an ethanol diluted suspension of the catalyst onto a copper grid coated with carbon film. The X-ray diffraction (XRD) spectra were conducted via a Rigaku D/Max-2500 X-ray diffractometer with a $\mathrm{Cu} \mathrm{K}_{\alpha}$ source recorded. X-ray photoelectron spectra (XPS) were collected on an ESCALAB 250xi X-ray photoelectron spectrometer using Al-Ka X-ray as the excitation source. All the spectra were corrected using C 1s signal located at $284.5 \mathrm{eV}$. Deconvolution of the spectra was carried out using the software XPS Peak 4.1 with thoroughly considering the constraints on binding energy, peak area and full width at half maximum. Metal contents in all catalysts were determined by the inductively coupled plasma atomic emission spectroscopy (ICP-AES, TJA RADIAL IRIS 1000).

\section{Electrochemical measurements}

The electrochemical measurements were conducted via a PARSTAT 2273 electrochemical workstation at room temperature. A three-electrode system which was composed of a glassy carbon electrode as the working electrode $\left(0.07065 \mathrm{~cm}^{2}\right.$ geometric area), a Pt sheet $\left(2 \times 2 \mathrm{~cm}^{2}\right)$ as counter electrode and a saturated $\mathrm{KCl} \mathrm{Hg} / \mathrm{HgCl}_{2}$ as reference electrode was employed for the electrochemical test. The nanocatalysts were treated by acetic acid to remove the surfactant before the tests. Typically, the as-prepared catalyst $(0.4 \mathrm{mg})$, Vulcan XC-72 $(1.6 \mathrm{mg})$ and Nafion solution $(10 \mu \mathrm{L}, 5.0 \mathrm{wt} \%)$ were dissolved in an ethanol aqueous $\left(1 \mathrm{~mL}, \mathrm{~V}_{\text {ethanol }} / \mathrm{V}_{\text {water }}=1 / 4\right)$ and then sonicated for $30 \mathrm{~min}$ to form a catalyst ink. Next, $3.0 \mu \mathrm{L}$ of ink (1.2 $\mu \mathrm{g}$ of nanocatalyst) was dropped onto the polished working electrode and dried at room temperature. Subsequently, the working electrode covered with catalyst was activated in $1.0 \mathrm{M} \mathrm{N}_{2}$-saturated $\mathrm{NaOH}$ solution via cyclic voltammetry $(\mathrm{CV})$ between $-0.9 \mathrm{~V}$ and $0.3 \mathrm{~V}$ (vs. SCE) at a scan rate of $50 \mathrm{mV} \mathrm{s}^{-1}$ until it approached to a steady state. The electrochemically active surface area (ECSA) of a catalyst can be calculated from the charge required for oxygen desorption, that is, from the area of the reduction peak of $\mathrm{PdO}$ in the cyclic voltammograms (CVs) in $1.0 \mathrm{M}^{\circ} \mathrm{N}_{2-}$ 
saturated $\mathrm{NaOH}$ solution. The $\mathrm{ECSA}_{H}\left(\mathrm{~m}^{2} \mathrm{~g}_{\mathrm{Pd}}{ }^{-1}\right)$ can be calculated by measuring the charge collected in the hydrogen adsorption/desorption region after double-layer correction and assuming a value of 210 $\mu \mathrm{C} \mathrm{cm}{ }^{-2}$ for the adsorption of a hydrogen monolayer in $0.5 \mathrm{M} \mathrm{H}_{2} \mathrm{SO}_{4}$ solution. ${ }^{[2]}$ The ethanol oxidation reaction (EOR) measurements were carried out in $\mathrm{N}_{2}$-saturated aqueous solution containing $1.0 \mathrm{M}$ $\mathrm{NaOH}$ and $1.0 \mathrm{M} \mathrm{C}_{2} \mathrm{H}_{5} \mathrm{OH}$ also between $-0.9 \mathrm{~V}$ and $0.3 \mathrm{~V}(v s . \mathrm{SCE})$ at a scan rate of $20 \mathrm{mV} \cdot \mathrm{s}^{-1}$. The stability of catalysts for EOR were estimated by chronoamperometry experiments carried out at a constant potential of $-0.2 \mathrm{~V}(v s . \mathrm{SCE})$ for $7200 \mathrm{~s}$. All electrochemical measurements were carried out at $30{ }^{\circ} \mathrm{C}$. Chronoamperometry (CA) tests were carried out at $-0.2 \mathrm{~V}(v s \mathrm{SCE})$ in $\mathrm{N}_{2}$-saturated $1.0 \mathrm{M} \mathrm{NaOH}$ solution containing $1.0 \mathrm{M}$ eth $\mathrm{C}_{2} \mathrm{H}_{5} \mathrm{OH}$ anol for a period of 7200 s. For accelerated durability tests (ADTs), potential cycling was conducted between $-0.9 \mathrm{~V}$ and $0.3 \mathrm{~V}$ ( vs. SCE) in $\mathrm{N}_{2}$-saturated aqueous solution containing $1.0 \mathrm{M} \mathrm{NaOH}$ and $1.0 \mathrm{M} \mathrm{C}_{2} \mathrm{H}_{5} \mathrm{OH}$ at a scan rate of $50 \mathrm{mV} \cdot \mathrm{s}^{-1}$ for 250 cycles. For $\mathrm{CO}$ stripping tests, $\mathrm{CO}$ oxidation experiments were carried out in the solution of $1.0 \mathrm{M} \mathrm{NaOH}$. Before the test, the solution was purged with $\mathrm{N}_{2}$ for 30 min and then was bubbled with $\mathrm{CO}(99.9 \%)$ for 15 min at $-0.7 \mathrm{~V}(v s . \mathrm{SCE})$ to achieve the maximum coverage of $\mathrm{CO}$ at the Pd active centers. The residual $\mathrm{CO}$ in the solution was excluded by $\mathrm{N}_{2}$ for $30 \mathrm{~min}$. Afterwards, the $\mathrm{CO}$ stripping was performed by sweeping from -0.9 to $0.3 \mathrm{~V}(v s . \mathrm{SCE})$ at a scan rate of $50 \mathrm{mV} \mathrm{s}^{-1}$. The ECSACO $\left(\mathrm{m}^{2} \mathrm{~g}_{\mathrm{Pd}}{ }^{-1}\right)$ is estimated according to the equation $\mathrm{ECSA}=\mathrm{Q} /\left(0.42 \times \mathrm{W}_{\mathrm{Pd}}\right),{ }^{[3]}$ where $\mathrm{Q}$ is the CO stripping charge $(\mathrm{mC})$ and $\mathrm{W}_{\mathrm{Pd}}$ stands for the Pd loading $\left(\mathrm{mg} \mathrm{cm}^{-2}\right)$ on the electrode. Meanwhile, $0.42\left(\mathrm{mC} \mathrm{cm} \mathrm{Pd}^{2}\right)$ corresponds to the CO stripping charge of a monolayer of adsorbed $\mathrm{CO}$ on $1 \mathrm{~cm}^{2}$ of surface.

\section{Electrochemical in situ Fourier Transform Infrared spectroscopy}

Electrochemical in situ FTIR spectroscopy (in situ FTIRs) measurements were conducted on a Nexus 8700 spectrometer (Nicolet) equipped with a liquid nitrogen-cooled MCT-A detector. A CaF 2 disk was used as the IR window, and an IR cell with a thin layer configuration between the electrode and the IR window was approached by pushing the electrode against the window before FTIR measurement. In situ FTIR spectra were collected using both single potential alteration FTIR spectroscopy (SPAFTIRS). The glassy carbon electrode, platinum black electrode and saturated calomel 
electrode used as the working electrode, counter electrode and reference electrode during SPAFTIRS experiments, respectively. The resulting spectra were reported as the relative change in reflectivity and calculated as follows:

$$
\frac{\Delta \mathrm{R}}{\mathrm{R}}=\frac{\mathrm{R}\left(E_{S}\right)-\mathrm{R}\left(E_{R}\right)}{\mathrm{R}\left(E_{R}\right)}
$$

where $\mathrm{R}\left(E_{\mathrm{S}}\right)$ and $\mathrm{R}\left(E_{\mathrm{R}}\right)$ are the single-beam spectrum obtained by Fourier transform processing of co-added and averaged interferograms collected at sample potential $E_{\mathrm{S}}$ and reference potential $E_{\mathrm{R}}$, respectively. By this definition, the downward bands in the resulting spectra indicate the formation of products, while upward bands denote the consumption of reactants. The $E_{\mathrm{R}}$ was fixed at $-0.80 \mathrm{~V}$ ( $v s$. SCE).

Prior to IR data collection, a clean procedure was applied to the $\mathrm{Au} @ \mathrm{O}-\mathrm{Pd}_{1} \mathrm{Cu}$ electrode, i.e., the electrode potential was first held at $0.2 \mathrm{~V}$ (vs. SCE) for $5.0 \mathrm{~s}$ to oxidize completely any adsorbates; then stepped negatively to $-0.80 \mathrm{~V}(v s$. SCE), where surface oxygen species was reduced, and the oxidation of ethanol did not occur, and its dissociative adsorption on $\mathrm{Au} @ \mathrm{O}-\mathrm{Pd}_{1} \mathrm{Cu}$ electrode could be neglected. Finally, the $\mathrm{Au} @ \mathrm{O}-\mathrm{Pd}_{1} \mathrm{Cu}$ electrode was pushed against the $\mathrm{CaF}_{2}$ IR window to form a thin-layer solution. It is worthwhile noticing that, prior to spectral collection at each $E_{\mathrm{S}}$, the $\mathrm{Au} @ \mathrm{O}-\mathrm{Pd}_{1} \mathrm{Cu}$ electrode was uplifted and cleaned by using the above clean procedure, and then it was pushed down to the IR window to form a thin-layer with renewed solution. In such a way, the initial conditions were the same for each spectrum, so the influence of product accumulation and reactant consumption in the thinlayer solution on in situ FTIR spectrum collected at different $E_{\mathrm{S}}$ has been avoided.

\section{Density functional theory (DFT) calculation}

Density functional theory (DFT) calculations were used to investigate the adsorption and reaction energetics of $\mathrm{OH}$ on $\mathrm{Pd}$ and $\mathrm{PdCu}$ surfaces. These calculations were performed using the projected augmented wave (PAW) method as implemented in the Vienna Ab initio simulation package (VASP) 5.4.4. ${ }^{[4,5]}$ The electron interactions were described using the Perdew-Burke-Ernzerhof (PBE) exchangecorrelation functional within the generalized gradient approximation (GGA) scheme. ${ }^{[6]}$ The kinetic cutoff energy for the plane-wave basis set was $700 \mathrm{eV}$. For geometric optimizations, the smearing 
method of Methfessel Paxton (MP) and smearing widths of $0.2 \mathrm{eV}$ were applied to all of the abovementioned metallic systems. ${ }^{[7]}$

To construct the surface slabs required to model $\mathrm{OH}$ adsorption, we first optimize the lattice constants of the corresponding bulk phases. For $f c c$-Pd unit cell with $4 \mathrm{Pd}$ atoms, our test indicated that a $24 \times 24 \times 24$ Monkhorst-Pack k-point mesh led to an energy difference less than $0.001 \mathrm{eV} /$ atom. The $24 \times 24 \times 24$ Monkhorst-Pack k-point mesh was also applied to $b c c-\mathrm{PdCu}(\mathrm{B} 2)$ and $f c c$-Cu unit cells. For $f c c-\mathrm{PdCu}$ bulk phase, previous studies proposed two kinds of structures, namely, $\mathrm{L} 1_{0}$ and $\mathrm{L} 1_{1}{ }^{[8]}$ Due to their different unit cell size, we applied $13 \times 13 \times 13$ and $6 \times 6 \times 6$ Monkhorst-Pack k-point mesh to achieve a similar computational accuracy. All bulk phases were optimized until the magnitude of the residual forces on the atoms was less than $0.001 \mathrm{eV} \AA^{-1}$.

For $\mathrm{OH}$ adsorption, a $3 \times 1$ rectangular unit cell for $\mathrm{PdCu}-\mathrm{L} 1_{0}(111), \mathrm{PdCu}-\mathrm{L} 1_{1}(111)$ and $\mathrm{PdCu}-$ B2 (110), and a $3 \times 2$ rectangular unit cell for $\mathrm{Pd}(111)$ and $\mathrm{Cu}$ (111) were found to be the smallest periodic unit. 1/3 ML OH arrangement was achieved for $\mathrm{OH}$ adsorption. All surface calculations used 4-layer slabs with the bottom two layers fixed to their bulk position, and the vacuum spaces between periodic images were set no less than $14 \AA$. Optimization was performed until the forces on the atoms were below $0.01 \mathrm{eV} \AA^{-1}$. Dipole corrections were included in all surface calculations in the surface normal direction for both energies and forces. The frequencies of the surface adsorbed species were computed using finite difference method, and zero-point energy as well as vibrational entropy was computed with standard methods and harmonic oscillator approximation to convert electronic DFT energy into free energy. ${ }^{[9]}$ The entropy term of free molecular species was referred to JANAF thermodynamic table. ${ }^{[10]}$ All DFT calculations were spin-unpolarized. The methods used to calculate the free energy of adsorption and the equilibrium adsorption potential for hydroxide follow those that have been described previously. ${ }^{[11]}$ 


\section{Supporting Figures}

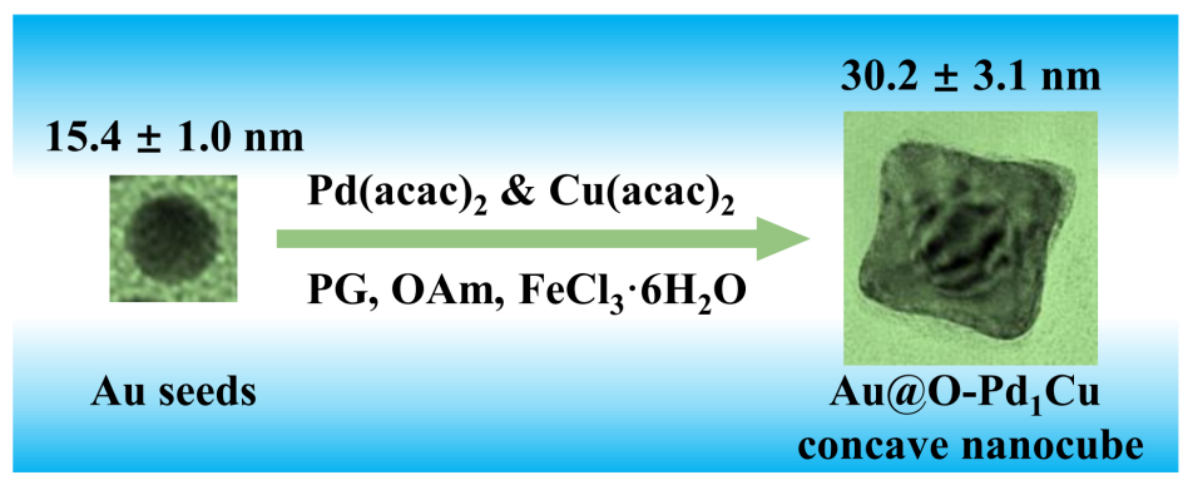

Figure S1 Schematic illustration of the heterogeneous seed-mediated syntheses of $\mathrm{Au} @ \mathrm{O}-\mathrm{Pd} \mathrm{C}_{1} \mathrm{Cu} \mathrm{CNCs}$. 

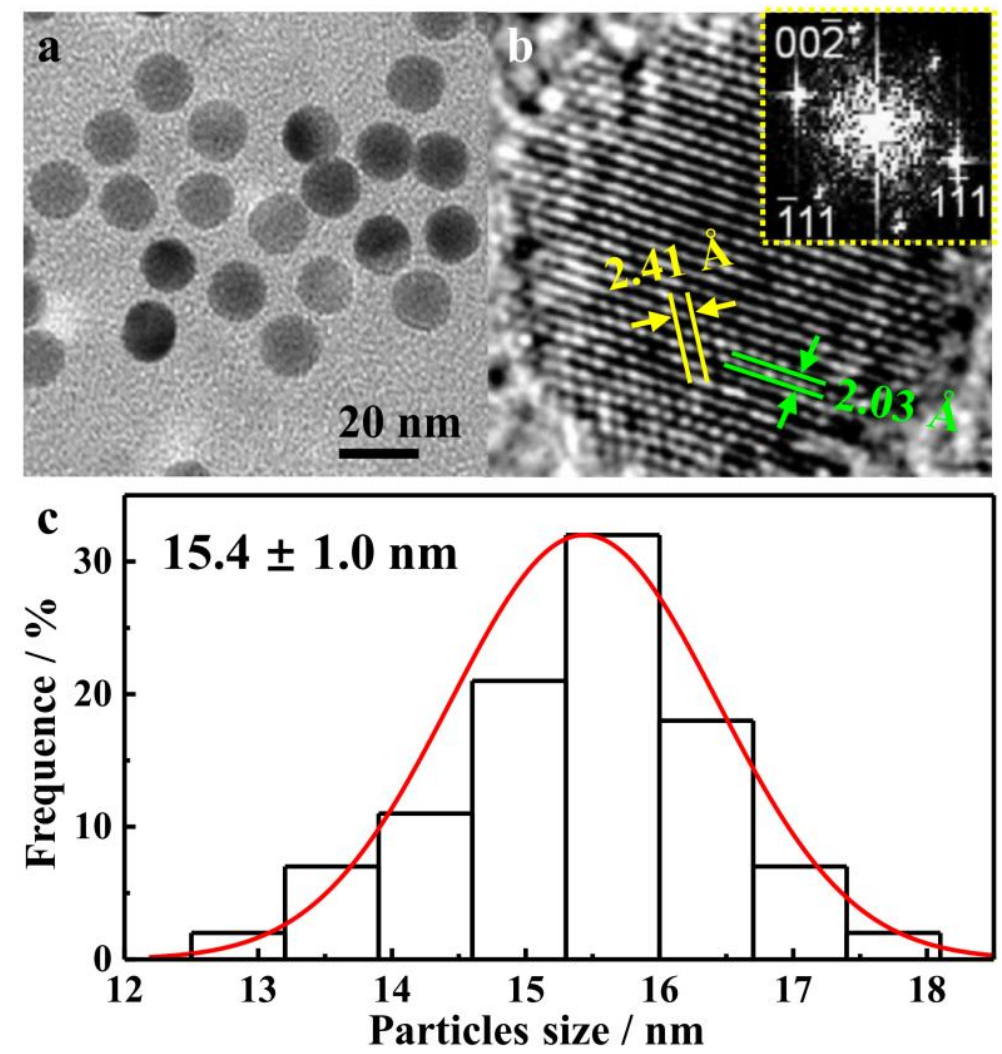

Figure S2 (a) TEM and (b) HRTEM images and corresponding FFT pattern (inset in Figure S2b), and (c) particle size histograms of Au seeds. 


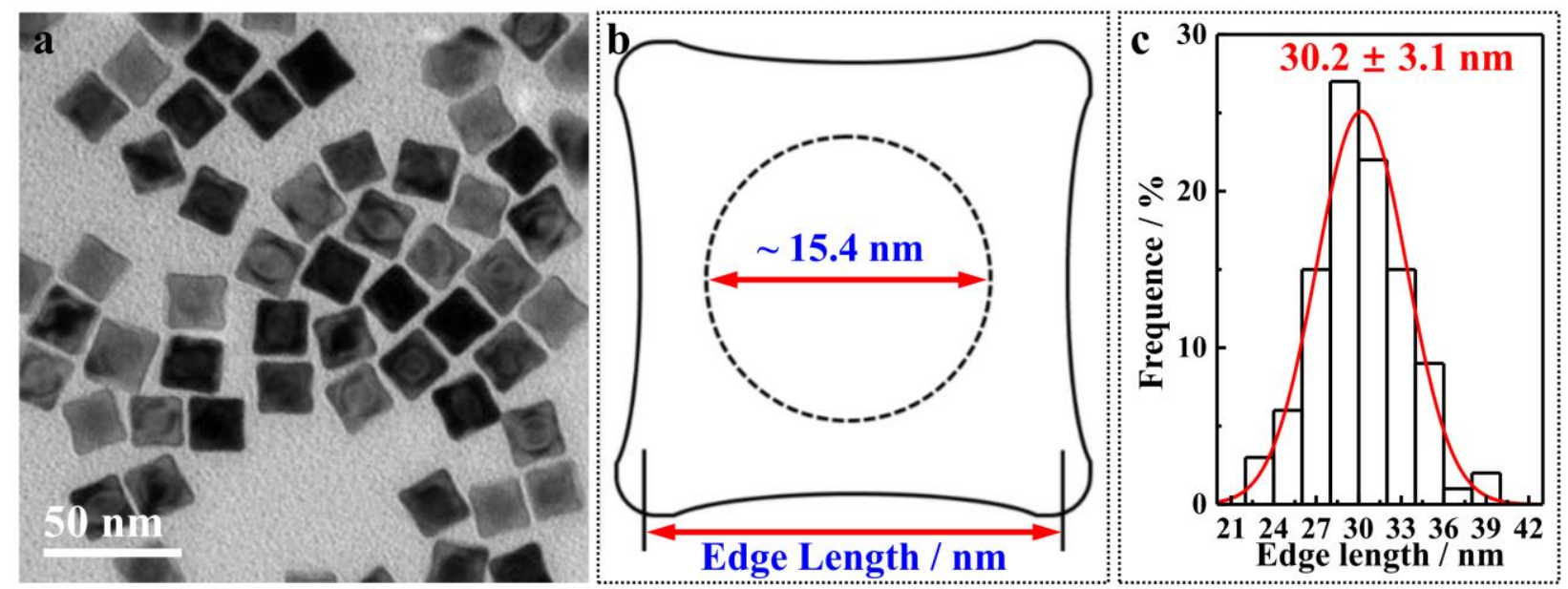

Figure S3 (a) TEM image of the $\mathrm{Au} @ \mathrm{O}-\mathrm{Pd}{ }_{1} \mathrm{Cu}$ CNCs; (b) Schematic illustration of the CNC and the corresponding definition of edge length; (c) The average edge length of $\mathrm{Au} @ \mathrm{O}-\mathrm{Pd}_{1} \mathrm{Cu} \mathrm{CNCs}$. 

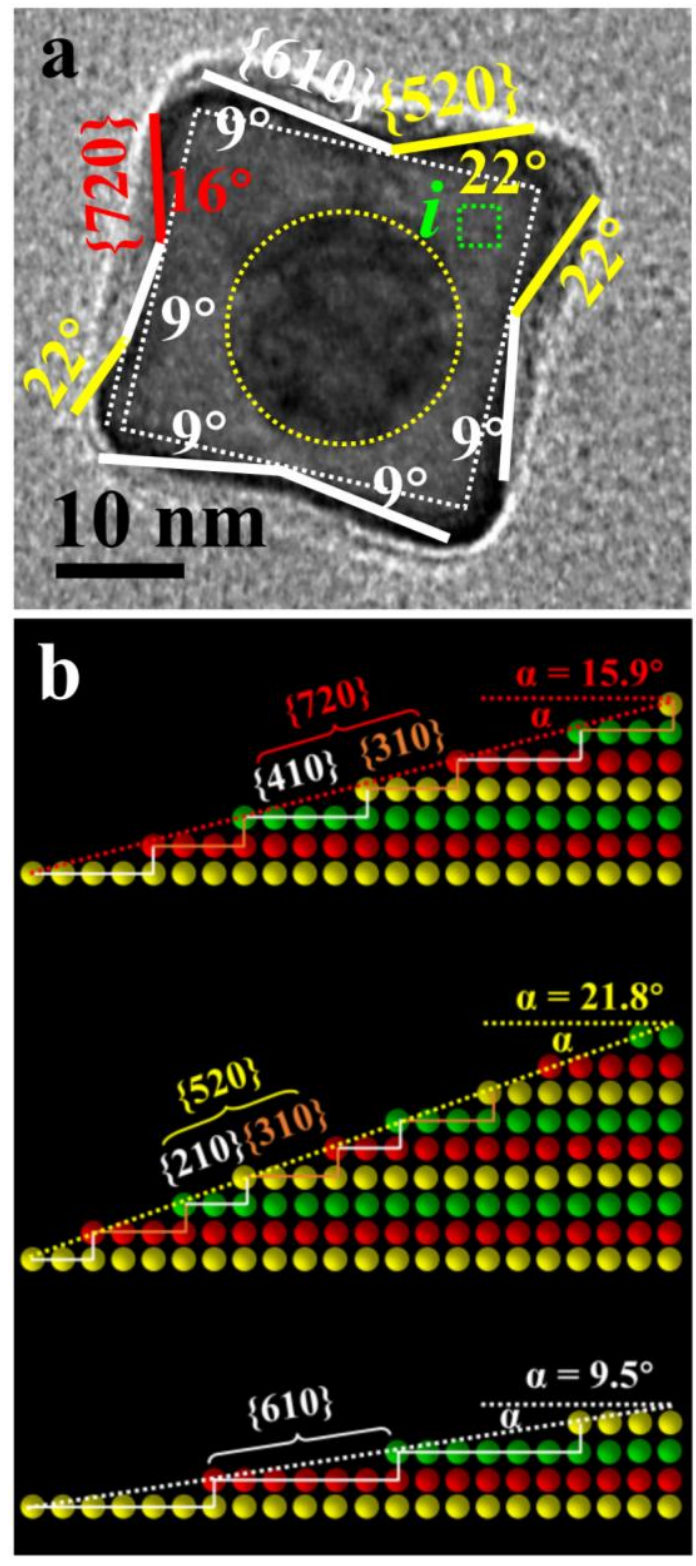

Figure S4 (a) TEM image of a single $\mathrm{Au} @ \mathrm{O}-\mathrm{Pd}_{1} \mathrm{Cu} \mathrm{CNC}$ and (b) atomic models of $\{610\},\{520\}$, and $\{720\}$ facets. 


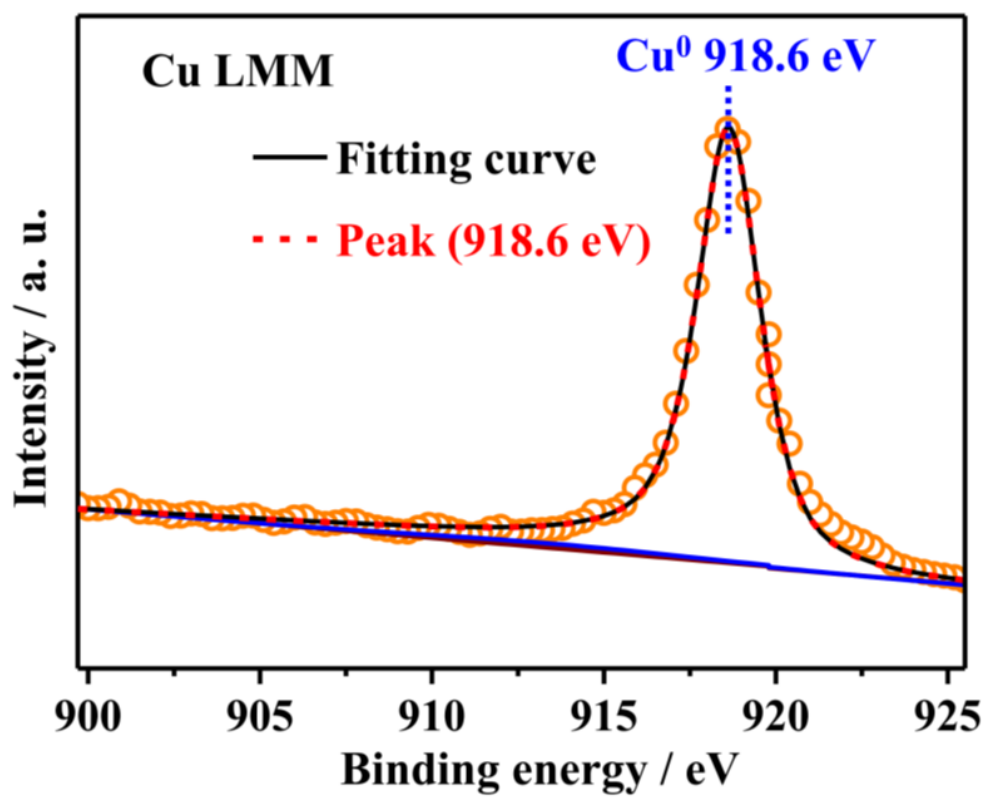

Figure S5 Cu LMM Auger spectra of $\mathrm{Au} @ \mathrm{O}-\mathrm{Pd}_{1} \mathrm{Cu} \mathrm{CNCs}$. 

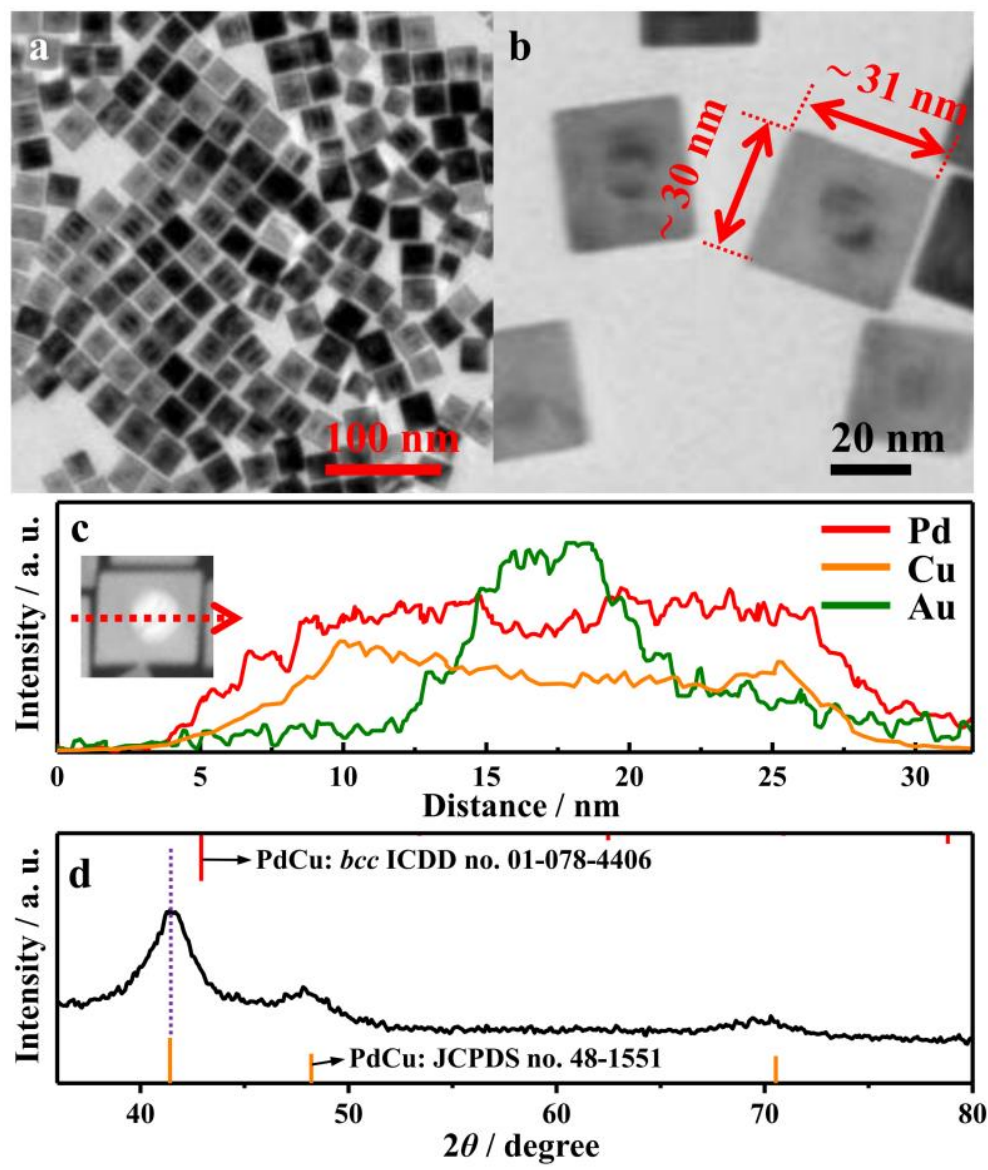

Figure S6 (a, b) TEM images, (c) EDS line scan and (d) XRD pattern of the $\mathrm{Au} @ \mathrm{D}-\mathrm{Pd} \mathrm{C}_{1} \mathrm{Cu} \mathrm{NCs}$. 


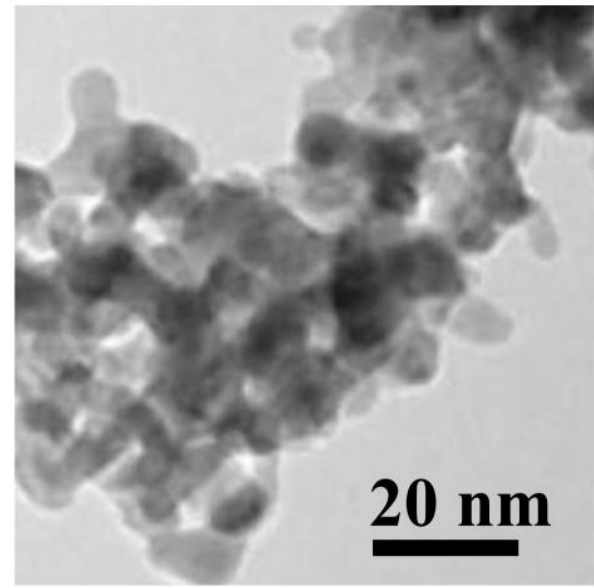

Figure S7 TEM image of the commercial Pd black. 


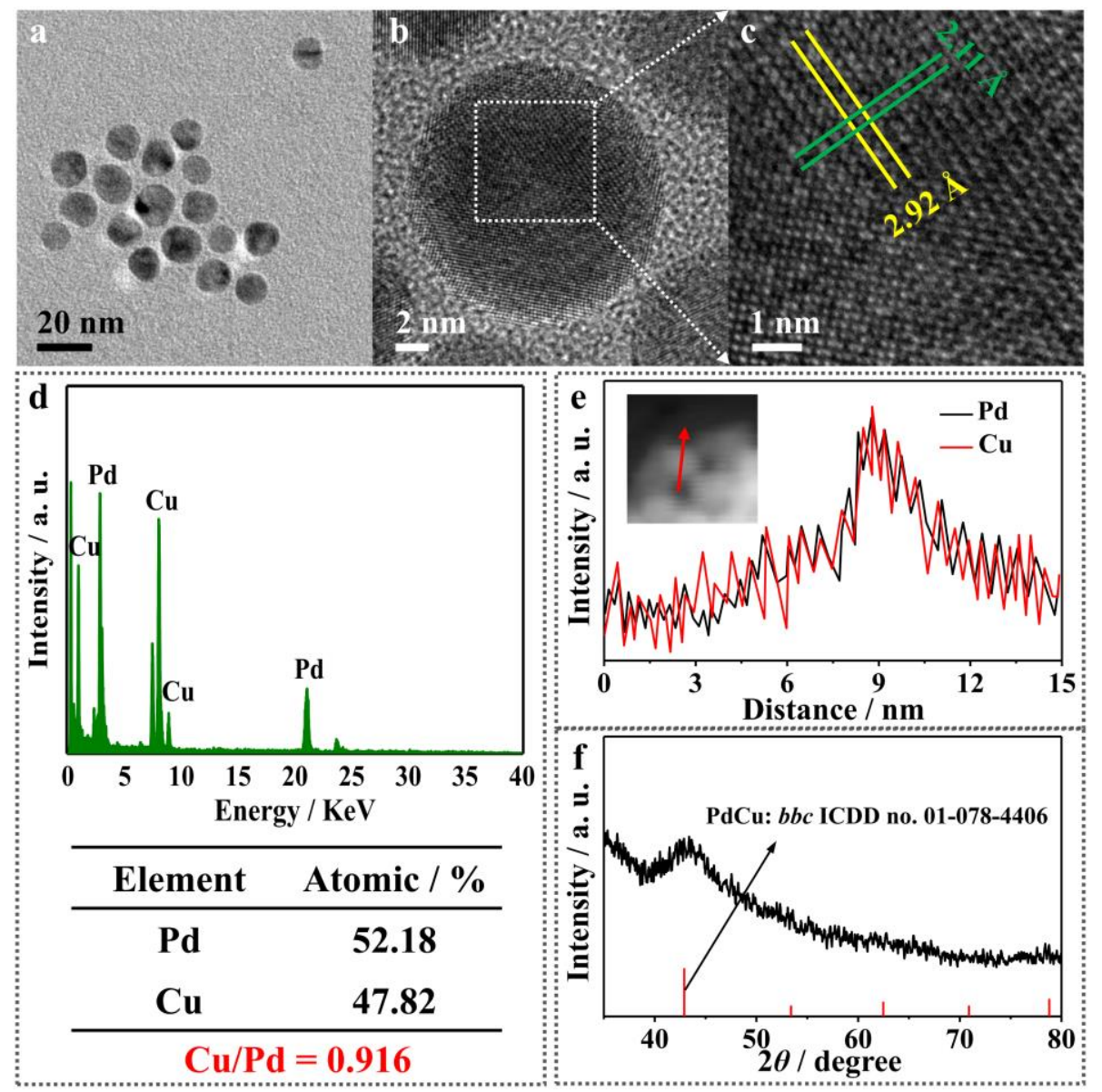

Figure S8 (a) TEM, (b and c) HRTEM images, (d) EDS, (e) line scan and (f) XRD pattern of O-Pd $\mathrm{Cu}$ NPs. 

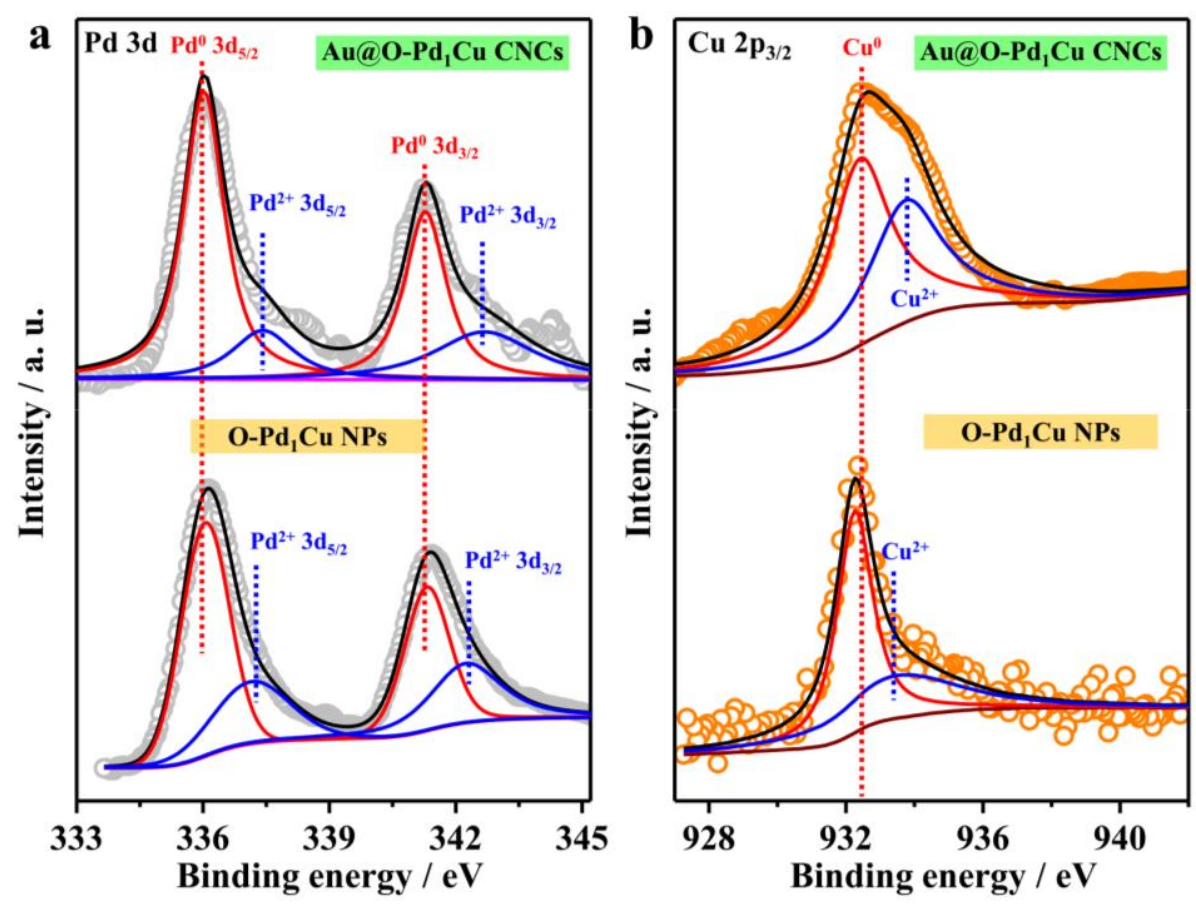

Figure S9 (a) Pd 3d and (b) $\mathrm{Cu} 2 \mathrm{p}_{3 / 2}$ XPS spectra of the $\mathrm{Au} @ \mathrm{O}-\mathrm{Pd}_{1} \mathrm{Cu} \mathrm{CNCs}$ and $\mathrm{O}-\mathrm{Pd}_{1} \mathrm{Cu} \mathrm{NPs}$. 

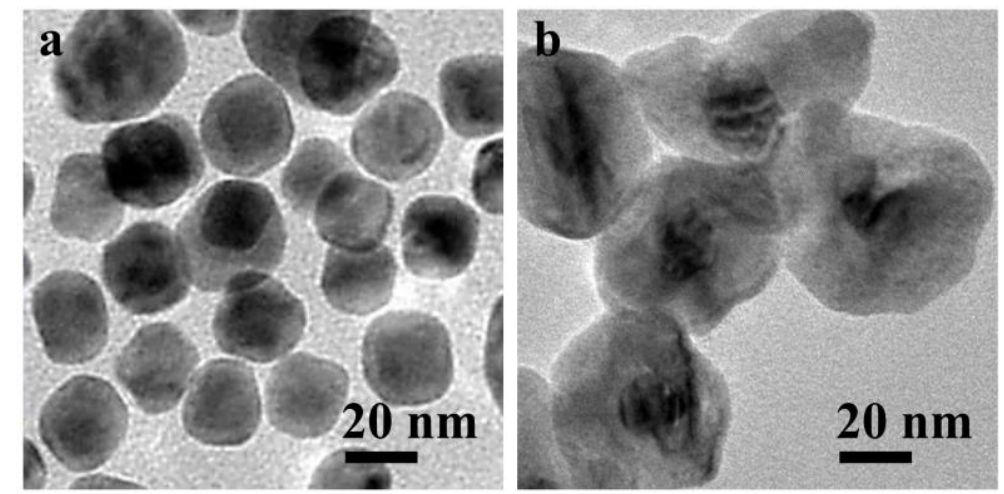

Figure S10 TEM images of the products with the same reaction conditions as those of $\mathrm{Au} @ \mathrm{O}-\mathrm{Pd}{ }_{1} \mathrm{Cu}$ CNCs except the uses of (a) $4.6 \mathrm{mg} \operatorname{Pd}(\mathrm{acac})_{2}$ and (b) $\left.18.4 \mathrm{mg} \mathrm{Pd(acac}\right)_{2}$. 

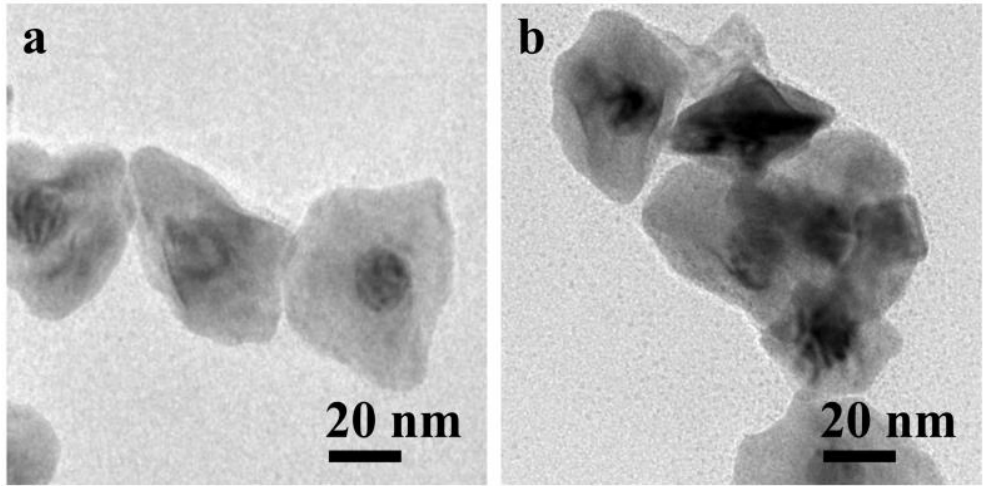

Figure S11 TEM images of the products with the same reaction conditions as those of $\mathrm{Au} @ \mathrm{O}-\mathrm{Pd}_{1} \mathrm{Cu}$ CNCs except the uses of (a) $4 \mathrm{mg} \mathrm{Cu}(\mathrm{acac})_{2}$ and (b) $15.8 \mathrm{mg} \mathrm{Cu}(\mathrm{acac})_{2}$. 


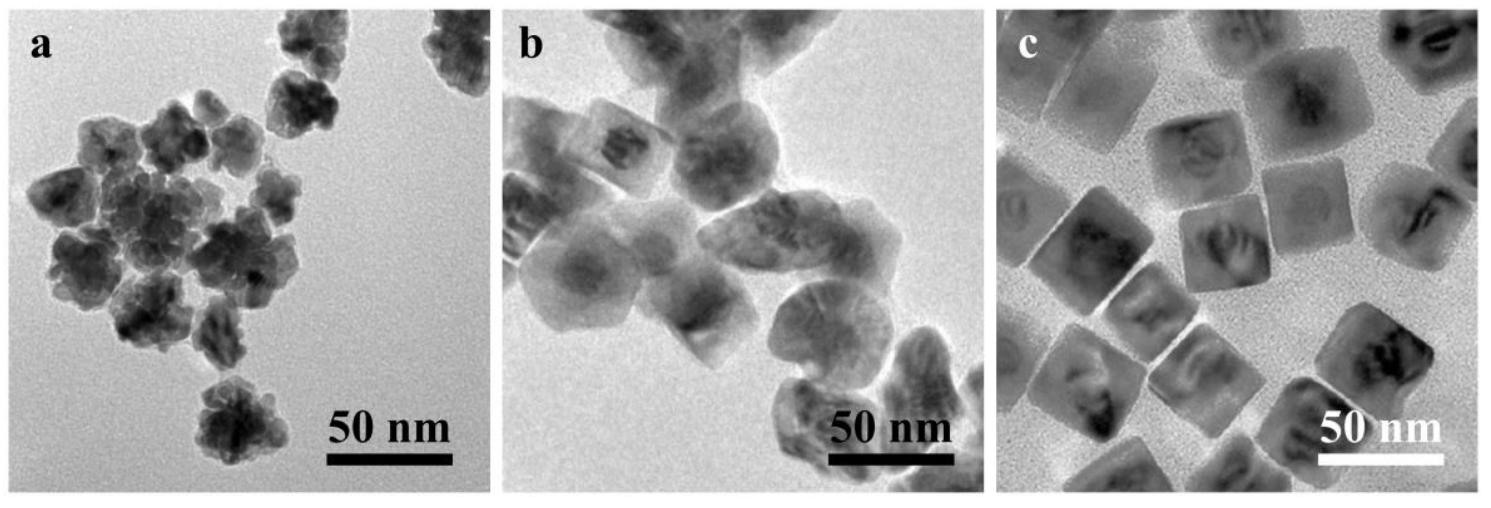

Figure S12 TEM images of the products with the same reaction conditions as those of $\mathrm{Au} @ \mathrm{O}-\mathrm{Pd}{ }_{1} \mathrm{Cu}$ CNCs except the uses of (a) $0 \mathrm{mg}$ CTAB, (b) $50 \mathrm{mg}$ CTAB and (c) $250 \mathrm{mg}$ CTAB. 

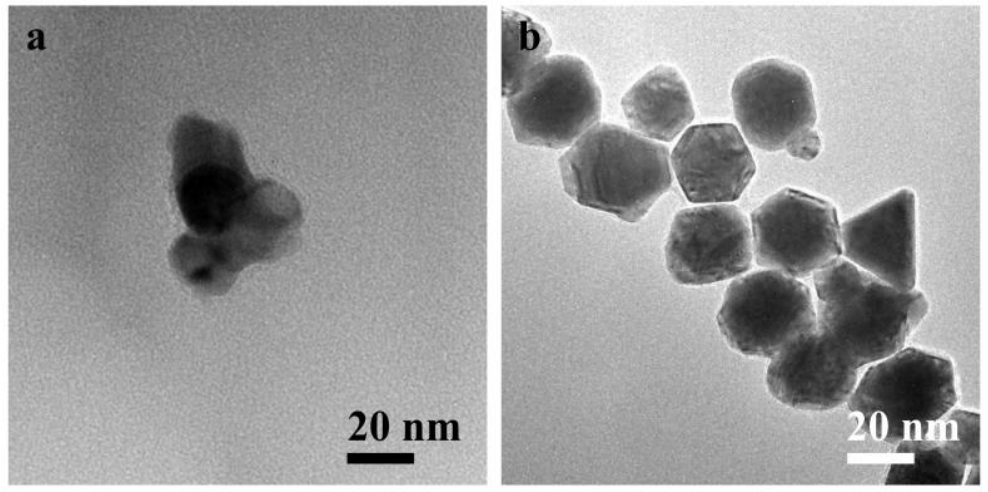

Figure S13 TEM images of the products with the same reaction conditions as those of $\mathrm{Au} @ \mathrm{O}-\mathrm{Pd}{ }_{1} \mathrm{Cu}$ CNCs but replacing $40 \mathrm{mg}$ PG with (a) $40 \mathrm{mg}$ glucose and (b) $40 \mathrm{mg}$ AA. 


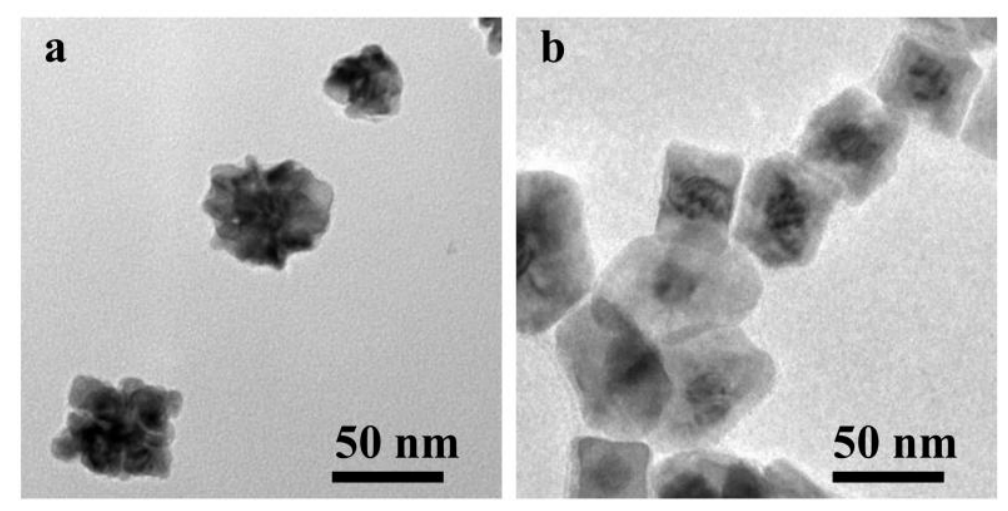

Figure S14 TEM images of the products with the same reaction conditions as those of $\mathrm{Au} @ \mathrm{O}-\mathrm{Pd}{ }_{1} \mathrm{Cu}$ CNCs except the uses of (a) $20 \mathrm{mg}$ PG and (b) $60 \mathrm{mg}$ PG. 


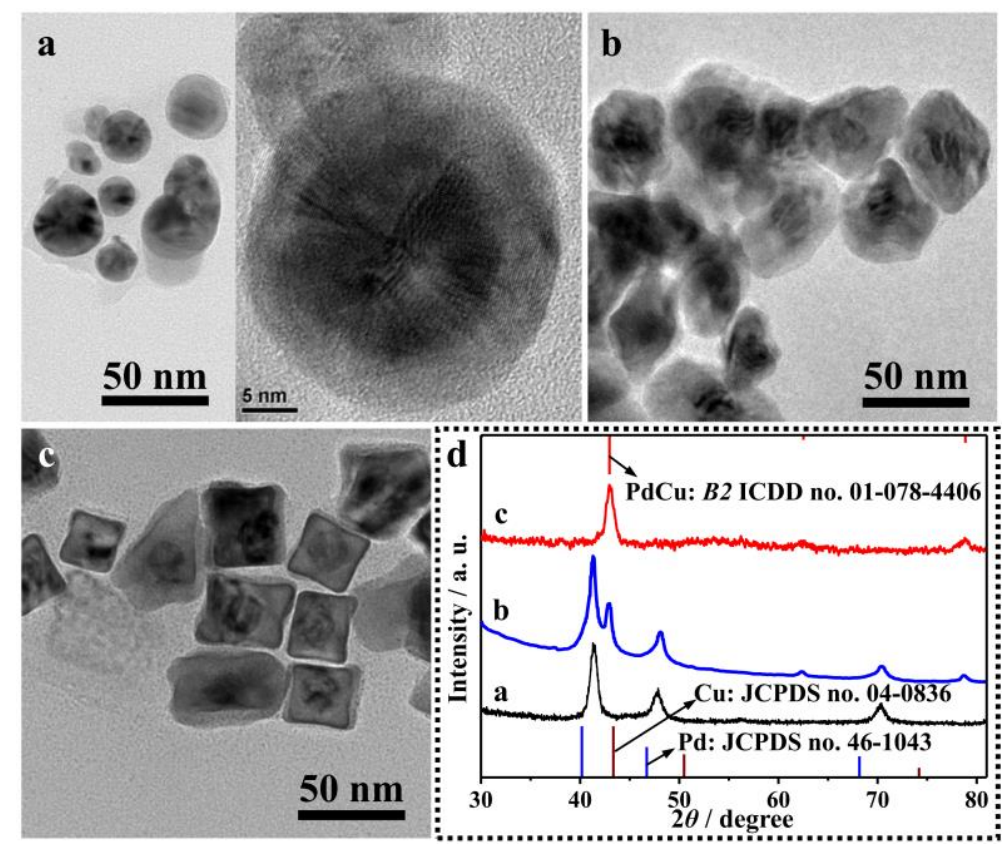

Figure S15 TEM images of the products with the same reaction conditions as those of $\mathrm{Au} @ \mathrm{O}-\mathrm{Pd}{ }_{1} \mathrm{Cu}$ CNCs except the uses of (a) $0 \mathrm{mg} \mathrm{FeCl} 3 \cdot 6 \mathrm{H}_{2} \mathrm{O}$, (b) $2.7 \mathrm{mg} \mathrm{FeCl} 3 \cdot 6 \mathrm{H}_{2} \mathrm{O}$ and (c) $8.1 \mathrm{mg} \mathrm{FeCl} \cdot 6 \mathrm{H}_{2} \mathrm{O}$; (d) XRD patterns of the above three samples. 


\section{$50 \mathrm{~nm}$}

Figure S16 TEM image of the products with the same reaction conditions as those of $\mathrm{Au} @ \mathrm{O}-\mathrm{Pd}{ }_{1} \mathrm{Cu}$ CNCs except the uses of $16.2 \mathrm{mg} \mathrm{FeCl}_{3} \cdot 6 \mathrm{H}_{2} \mathrm{O}$. 

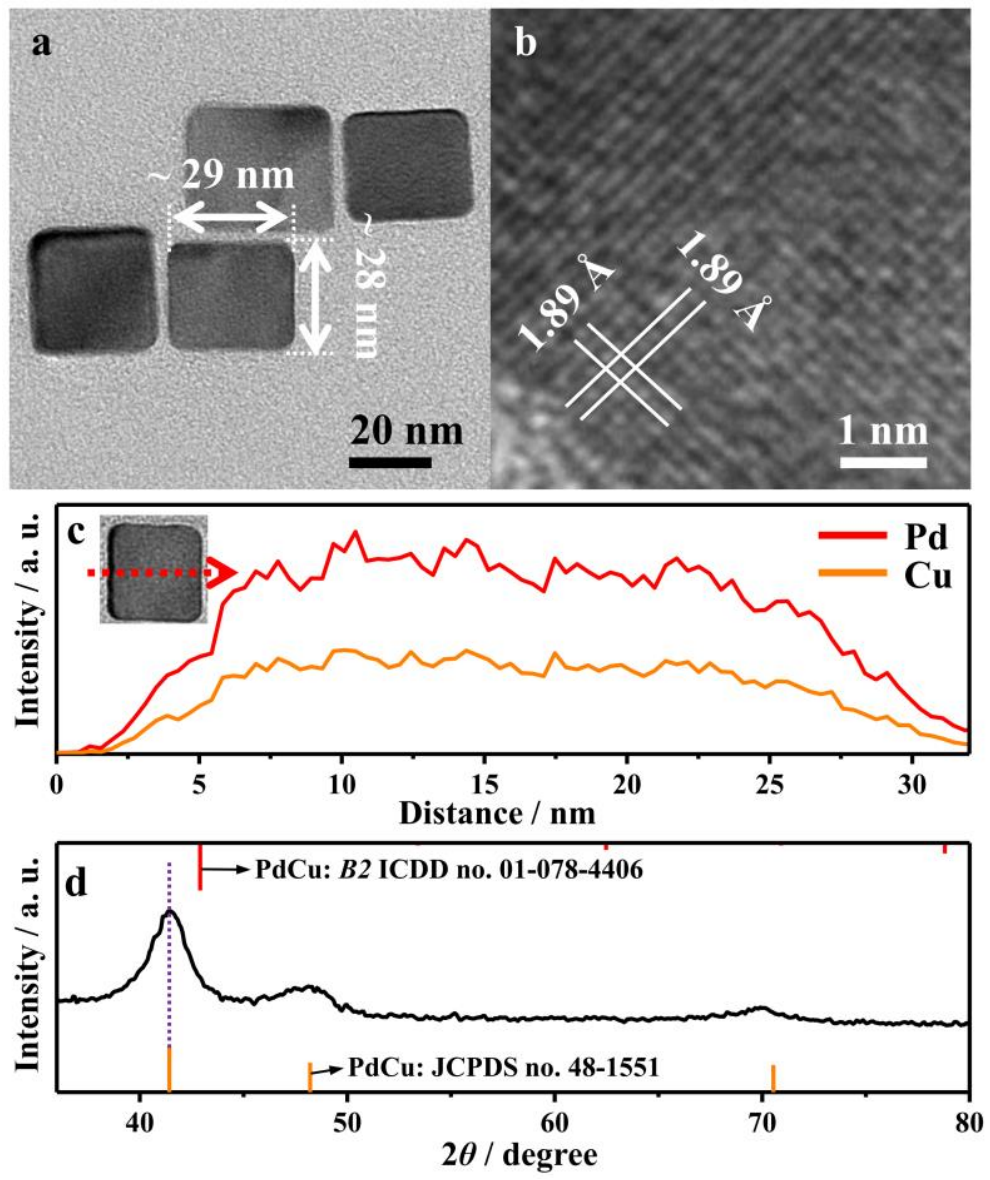

Figure S17 (a) TEM and (b) HRTEM images, (c) EDS line scan and (d) XRD pattern of the D-Pd ${ }_{1} \mathrm{Cu}$ NCs. 

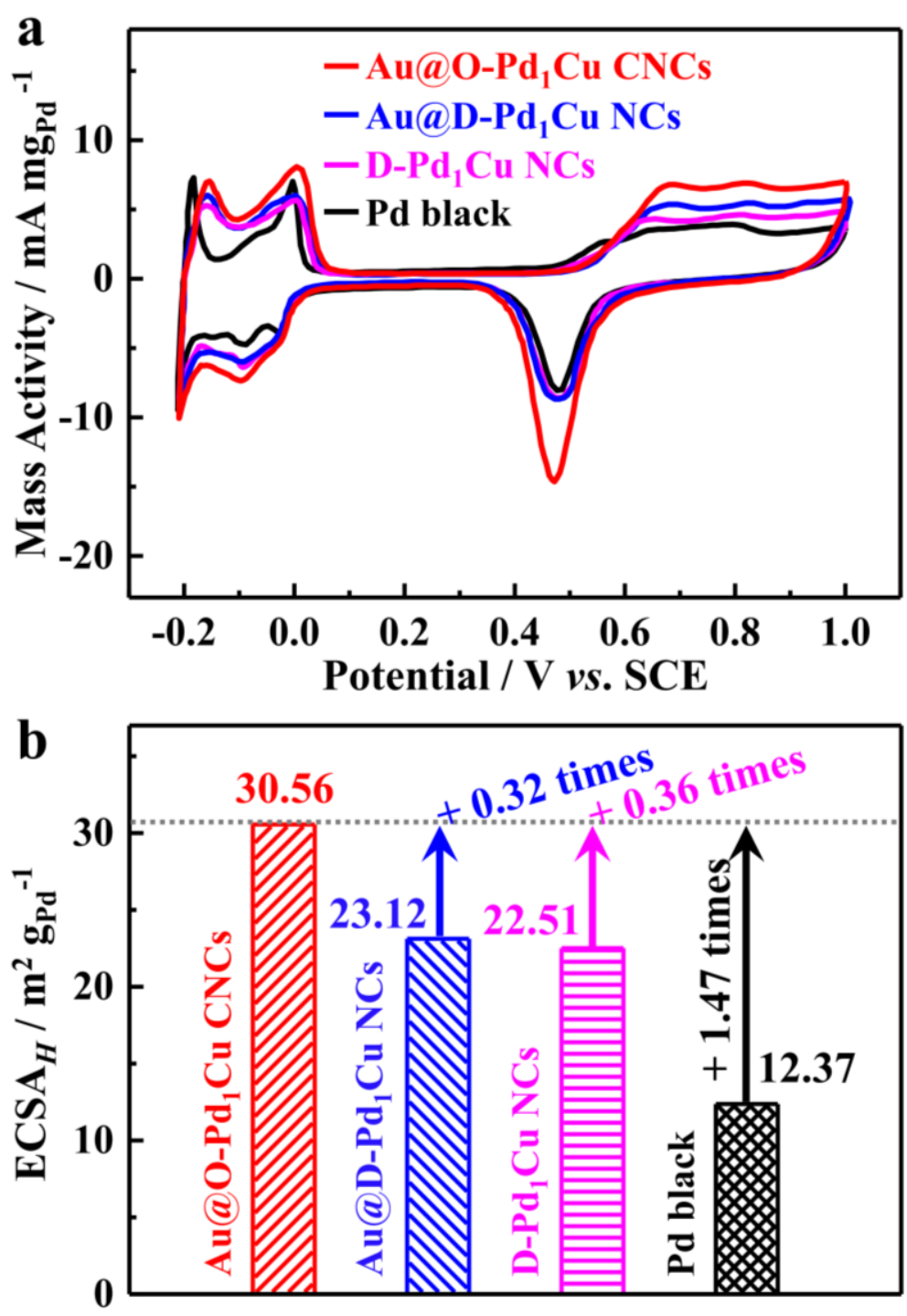

Figure S18 (a) CVs of the $\mathrm{Au} @ \mathrm{O}-\mathrm{Pd}_{1} \mathrm{Cu}$ CNCs, $\mathrm{Au} @ \mathrm{D}-\mathrm{Pd} \mathrm{d}_{1} \mathrm{Cu} \mathrm{NCs}$, D-Pd ${ }_{1} \mathrm{Cu}$ NCs and Pd black in 0.5 $\mathrm{M} \mathrm{H}_{2} \mathrm{SO}_{4}$ solution with the cyclic potential scanning between -0.2 and $1.0 \mathrm{~V}$ ( $v s$. SCE) at a scan rate of $50 \mathrm{mV} \mathrm{s}^{-1}$; (b) Histograms of ECSA $\mathrm{E}_{H}$ of the $\mathrm{Au} @ \mathrm{O}-\mathrm{Pd}_{1} \mathrm{Cu} \mathrm{CNCs}, \mathrm{Au} @ \mathrm{D}-\mathrm{Pd}_{1} \mathrm{Cu} \mathrm{NCs}, \mathrm{D}-\mathrm{Pd} \mathrm{Cu}_{1} \mathrm{NCs}$ and Pd black. 


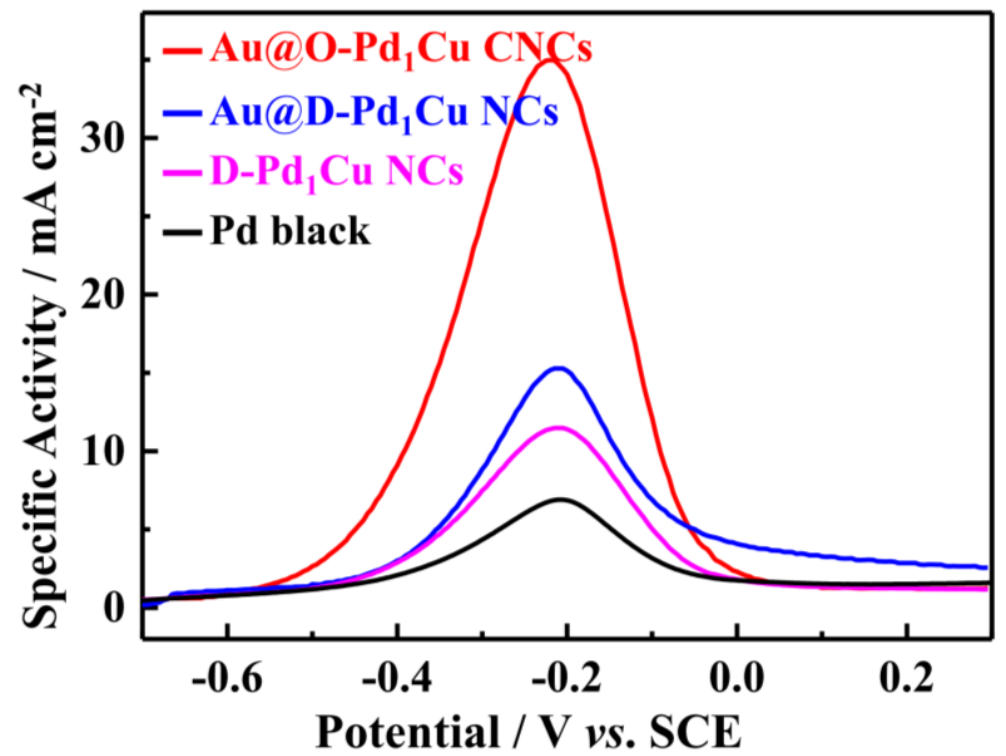

Figure S19 Forward voltammetric scans of the $\mathrm{Au} @ \mathrm{O}-\mathrm{Pd}_{1} \mathrm{Cu} \mathrm{CNCs}, \mathrm{Au} @ \mathrm{D}-\mathrm{Pd}_{1} \mathrm{Cu} \mathrm{NCs}, \mathrm{D}-\mathrm{Pd}{ }_{1} \mathrm{Cu}$ NCs and Pd black toward EOR measured in $\mathrm{N}_{2}$-saturated $1.0 \mathrm{M} \mathrm{NaOH}$ solution containing $1.0 \mathrm{M}$ $\mathrm{C}_{2} \mathrm{H}_{5} \mathrm{OH}$ at a scan rate of $50 \mathrm{mV} \mathrm{s}^{-1}$. 


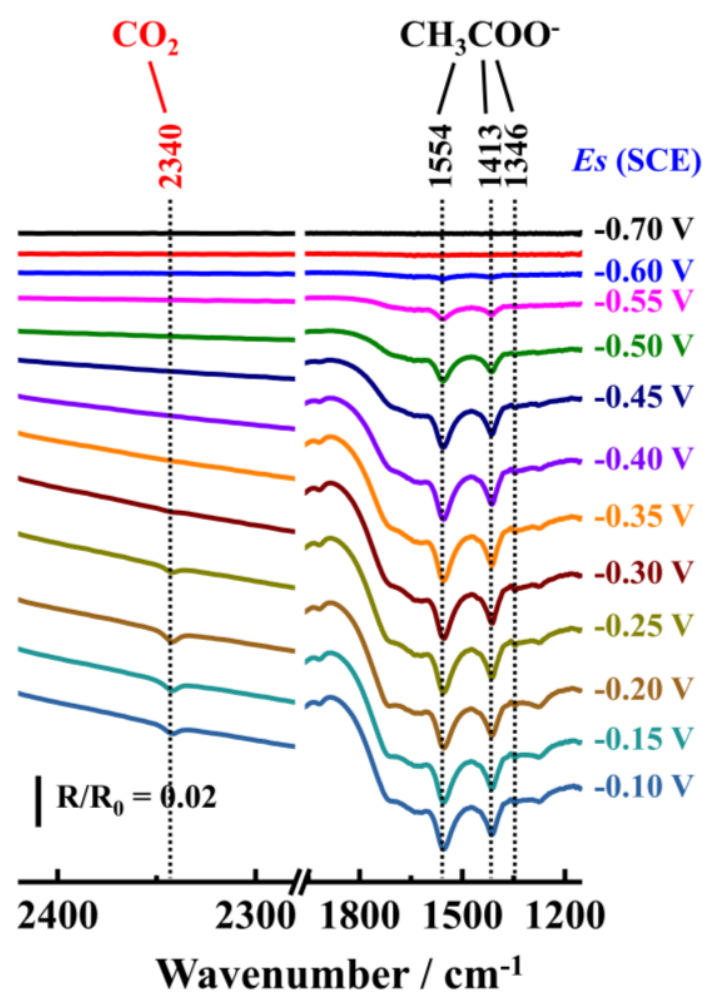

Figure S20 In-situ FTIR spectra of the $\mathrm{Au} @ \mathrm{O}-\mathrm{Pd} d_{1} \mathrm{Cu} \mathrm{CNCs}$ for EOR in $1.0 \mathrm{M} \mathrm{NaOH}$ solution containing $1.0 \mathrm{M} \mathrm{C}_{2} \mathrm{H}_{5} \mathrm{OH}$ at potentials varying from -0.7 to $-0.1 \mathrm{~V}$ at an interval of $0.05 \mathrm{~V}$. 


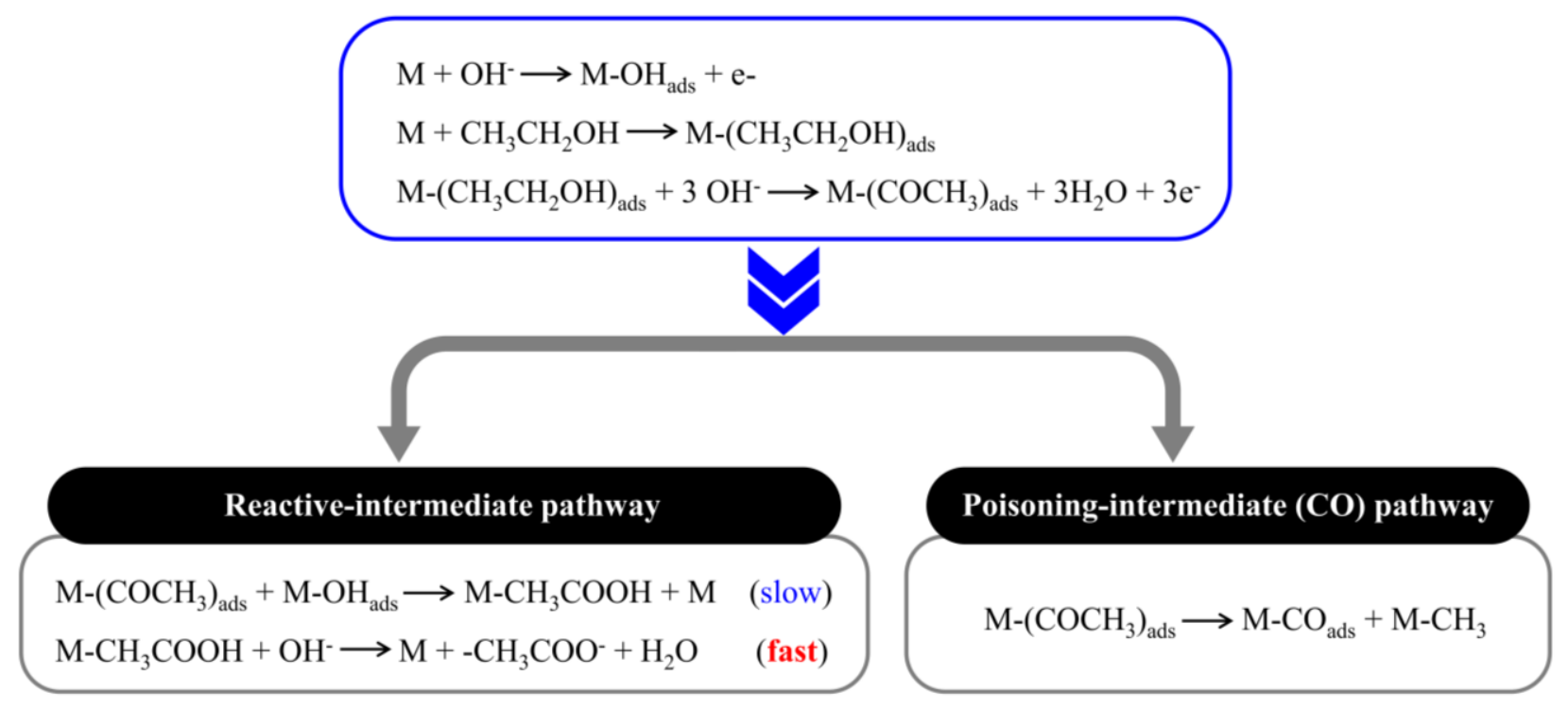

Figure S21 The reactive-intermediate and the poisoning-intermediate (CO) pathway for ethanol electrooxidation reaction in alkaline media. 
$\mathbf{a}$
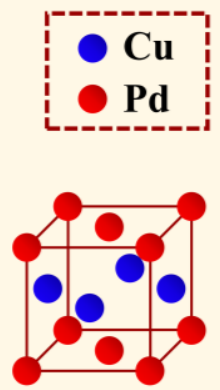

fcc-L1 ${ }_{0} \mathrm{Pd}_{1} \mathrm{Cu}$ unit-cell $a=b=c=3.82 \AA$

b

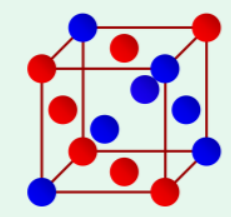

$f c c-\mathrm{L1}_{1} \mathrm{Pd}_{1} \mathrm{Cu}$ unit-cell $\mathrm{a}=\mathrm{b}=\mathrm{c}=\mathbf{2 . 7 1 \AA}$

c

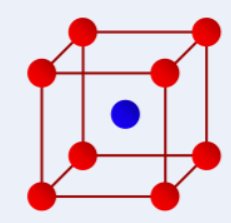

$b c c-B 2 \mathrm{Pd}_{1} \mathrm{Cu}$ unit-cell $\mathbf{a}=\mathbf{b}=\mathbf{c}=3.02 \AA$

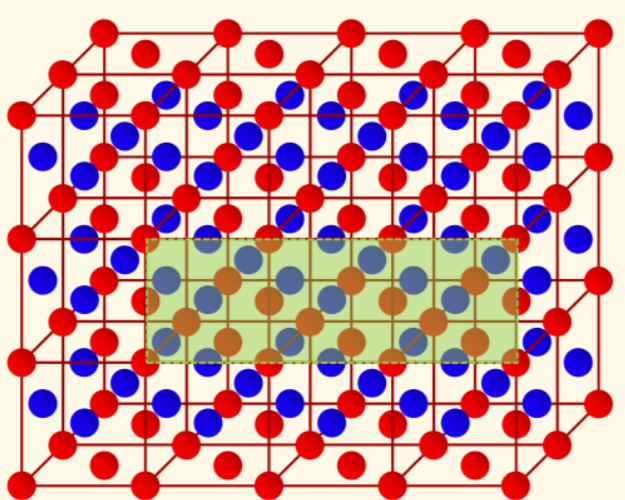

$\mathrm{Pd}_{1} \mathrm{Cu}-\mathrm{L1}_{0}$ (111) side view

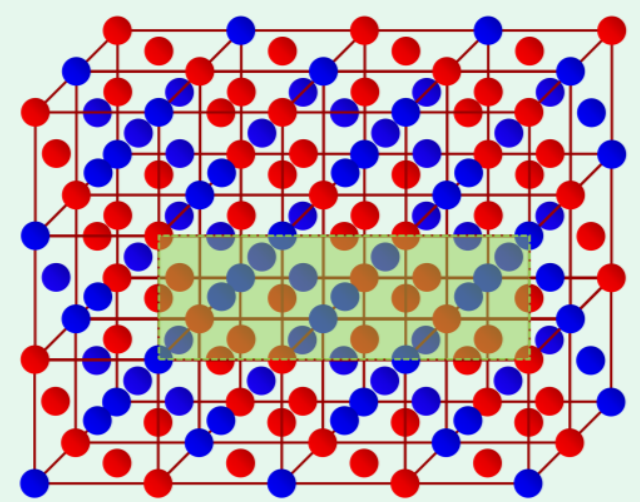

$\mathrm{Pd}_{1} \mathrm{Cu}-\mathrm{L1}_{1}$ (111) side view

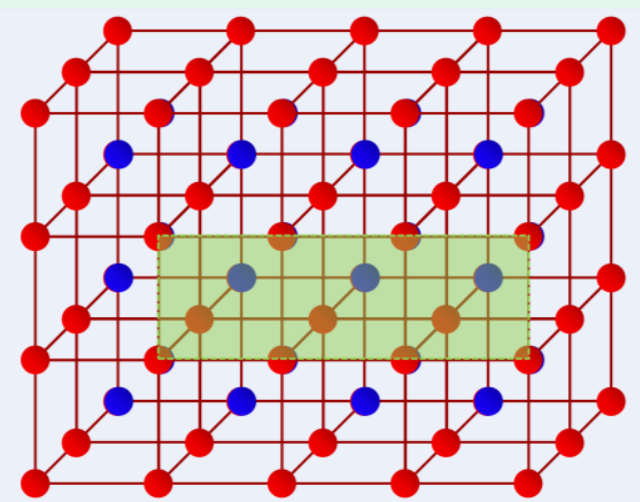

$\mathrm{Pd}_{1} \mathrm{Cu}-\mathrm{B} 2$ (110) side view

Figure S22 $f c c$ - and $b c c-\mathrm{Pd}_{1} \mathrm{Cu}$ unit cells and surface structures of $\mathrm{Pd}_{1} \mathrm{Cu}-\mathrm{L} 1_{0}(111), \mathrm{Pd}_{1} \mathrm{Cu}-\mathrm{L} 1_{1}(111)$ and $\mathrm{Pd}_{1} \mathrm{Cu}-\mathrm{B} 2(110)$. 


\section{Supporting Tables}

Table S1 Composition data of $\mathrm{Au} @ \mathrm{O}-\mathrm{Pd}{ }_{1} \mathrm{Cu} \mathrm{CNCs}$ intermediates collected from the reactions at different reaction times which were detected by ICP-AES.

\begin{tabular}{cccccc}
\hline $\begin{array}{c}\text { Reaction time } \\
/ \mathbf{m i n}\end{array}$ & $\begin{array}{c}\mathbf{C u} \\
/ \boldsymbol{\mu g} \mathbf{~ m L}^{-\mathbf{1}}\end{array}$ & $\begin{array}{c}\mathbf{P d} \\
/ \boldsymbol{\mu g} \mathbf{~ m L}^{-\mathbf{1}}\end{array}$ & $\begin{array}{c}\mathbf{A u} \\
/ \boldsymbol{\mu g} \mathbf{~ m L}^{-\mathbf{1}}\end{array}$ & $\begin{array}{c}\mathbf{C u}: \mathbf{P d}: \mathbf{A u} \\
/ \mathbf{a t}: \mathbf{a t}: \mathbf{a t}\end{array}$ & $\begin{array}{c}\mathbf{C u} / \mathbf{P d} \\
/ \mathbf{~ m o l} / \mathbf{~ m o l}\end{array}$ \\
\hline 0 & 0 & 0 & 100 & $0: 0: 1$ & - \\
10 & 0 & 12.7 & 87.3 & $0: 1: 3.7$ & 0 \\
30 & 30.3 & 18.2 & 51.5 & $2.78: 1: 1.52$ & 2.78 \\
90 & 28.4 & 34.9 & 36.7 & $1.36: 1: 0.57$ & 1.36 \\
180 & 25.4 & 41.1 & 33.5 & $1.03: 1: 0.44$ & 1.03 \\
\hline
\end{tabular}


Table S2 Composition data of $\mathrm{Au} @ \mathrm{O}-\mathrm{Pd}{ }_{1} \mathrm{Cu} \mathrm{CNCs}, \mathrm{Au} @ \mathrm{D}-\mathrm{Pd}_{1} \mathrm{Cu}$ NCs and D-Pd ${ }_{1} \mathrm{Cu}$ NCs detected by ICP-AES.

\begin{tabular}{|c|c|c|c|c|c|c|}
\hline Catalyst & $\begin{array}{c}\mathrm{Cu} \\
/ \mu \mathrm{g} \mathrm{mL} \mathbf{m}^{-1}\end{array}$ & $\begin{array}{c}\text { Pd } \\
/ \mu \mathrm{g} \mathrm{m \mathbf { } ^ { - 1 }} \\
\end{array}$ & $\begin{array}{c}\mathrm{Au} \\
/ \mu \mathrm{g} \mathrm{mL^{-1 }}\end{array}$ & $\begin{array}{c}\mathrm{Cu}: \mathrm{Pd}: \mathrm{Au} \\
/ \text { at }: \text { at }: \text { at }\end{array}$ & $\begin{array}{c}\mathrm{Cu} / \mathrm{Pd} \\
/ \mathrm{mol} / \mathrm{mol} \\
\end{array}$ & $\begin{array}{c}\text { Pd } \\
/ \mathbf{w t} \% \\
\end{array}$ \\
\hline $\begin{array}{c}\mathrm{Au} @ \mathrm{O}-\mathrm{Pd}_{1} \mathrm{Cu} \\
\mathrm{CNCs}\end{array}$ & 25.4 & 41.1 & 33.5 & $1.03: 1: 0.44$ & 1.03 & 41.1 \\
\hline $\mathrm{Au} @ \mathrm{D}-\mathrm{Pd}_{1} \mathrm{Cu} \mathrm{NCs}$ & 23.7 & 43.7 & 31.2 & $0.92: 1: 0.39$ & 0.92 & 44.3 \\
\hline $\mathrm{D}-\mathrm{Pd}_{1} \mathrm{Cu} \mathrm{NCs}$ & 37.2 & 58.8 & - & - & 1.06 & 61.7 \\
\hline
\end{tabular}


Table S3 Results of $\mathrm{Au} @ \mathrm{O}-\mathrm{Pd}_{1} \mathrm{Cu} \mathrm{CNCs}, \mathrm{Au} @ \mathrm{D}-\mathrm{Pd}_{1} \mathrm{Cu} \mathrm{NCs}, \mathrm{D}-\mathrm{Pd}_{1} \mathrm{Cu}$ NCs and Pd black used in the EOR.

\begin{tabular}{|c|c|c|c|c|c|}
\hline Catalyst & $\begin{array}{c}\mathbf{E C S A}_{H} \\
/ \mathbf{m}^{2} \mathbf{g}_{\mathbf{P d}}{ }^{-1} \\
\end{array}$ & $\begin{array}{l}\mathbf{E C S A}_{C O} \\
/ \mathrm{m}^{2} \mathrm{~g}_{\mathbf{P d}}{ }^{-1} \\
\end{array}$ & $\begin{array}{c}\mathbf{S A} \\
/ \mathbf{m A} \mathbf{~ c m}^{-2} \\
\end{array}$ & $\begin{array}{c}\text { MA } \\
/ \mathbf{A ~ m g}_{\mathbf{P d}^{-1}} \\
\end{array}$ & $\begin{array}{l}\text { Tafel slope } \\
\text { / mV dec } \\
\end{array}$ \\
\hline $\mathrm{Au} @ \mathrm{O}-\mathrm{Pd}_{1} \mathrm{Cu} \mathrm{CNCs}$ & 30.56 & 37.25 & 34.66 & 10.59 & 142.4 \\
\hline $\mathrm{Au} @ \mathrm{D}-\mathrm{Pd}_{1} \mathrm{Cu} \mathrm{NCs}$ & 23.12 & 28.56 & 14.78 & 3.42 & 193.1 \\
\hline $\mathrm{D}-\mathrm{Pd}_{1} \mathrm{Cu} \mathrm{NCs}$ & 22.51 & 28.12 & 10.93 & 2.46 & 205.3 \\
\hline Pd black & 12.37 & 13.16 & 6.75 & 0.84 & 299.5 \\
\hline
\end{tabular}


Table S4 List of mass peak current densities for EOR of some previously reported EOR catalysts.

\begin{tabular}{|c|c|c|c|c|}
\hline Catalyst & Condition & Scan Rate & MA / A mgPd ${ }^{-1}$ & Ref. \\
\hline $\mathrm{Au} @ 0-\mathrm{Pd}_{1} \mathrm{Cu} \mathrm{CNCs}$ & $1.0 \mathrm{M} \mathrm{NaOH}+1.0 \mathrm{M} \mathrm{C}_{2} \mathrm{H}_{5} \mathrm{OH}$ & $50 \mathrm{mV} \cdot \mathrm{s}^{-1}$ & 10.59 & $\begin{array}{l}\text { This } \\
\text { work }\end{array}$ \\
\hline $\mathrm{Pd}_{40} \mathrm{Ni}_{43} \mathrm{P}_{17}$ & $1.0 \mathrm{M} \mathrm{NaOH}+1.0 \mathrm{M} \mathrm{C}_{2} \mathrm{H}_{5} \mathrm{OH}$ & $100 \mathrm{mV} \cdot \mathrm{s}^{-1}$ & 4.95 & [12] \\
\hline $\mathrm{Pd} / \mathrm{ATN}-\mathrm{BP}-30 \%$ & $1.0 \mathrm{M} \mathrm{NaOH}+1.0 \mathrm{M} \mathrm{C}_{2} \mathrm{H}_{5} \mathrm{OH}$ & $50 \mathrm{mV} \cdot \mathrm{s}^{-1}$ & 5.02 & [13] \\
\hline $\mathrm{Pd} / \mathrm{ATN}-\mathrm{BP}-20 \%$ & $1.0 \mathrm{M} \mathrm{NaOH}+1.0 \mathrm{M} \mathrm{C}_{2} \mathrm{H}_{5} \mathrm{OH}$ & $50 \mathrm{mV} \cdot \mathrm{s}^{-1}$ & 4.98 & [13] \\
\hline $\mathrm{Pd}_{83} \mathrm{Ni}_{17} \mathrm{HNS}$ aerogel & $1.0 \mathrm{M} \mathrm{NaOH}+1.0 \mathrm{M} \mathrm{C}_{2} \mathrm{H}_{5} \mathrm{OH}$ & $50 \mathrm{mV} \cdot \mathrm{s}^{-1}$ & 3.63 & [14] \\
\hline $\mathrm{Pd}_{77} \mathrm{Cu}_{23}$ aerogel & $1.0 \mathrm{M} \mathrm{KOH}+1.0 \mathrm{M} \mathrm{C}_{2} \mathrm{H}_{5} \mathrm{OH}$ & $50 \mathrm{mV} \cdot \mathrm{s}^{-1}$ & 3.47 & {$[15]$} \\
\hline Au@PdAuCu MNSs & $1.0 \mathrm{M} \mathrm{KOH}+1.0 \mathrm{M} \mathrm{C}_{2} \mathrm{H}_{5} \mathrm{OH}$ & $50 \mathrm{mV} \cdot \mathrm{s}^{-1}$ & 3.99 & {$[16]$} \\
\hline Au@Pd NRs & $1.0 \mathrm{M} \mathrm{KOH}+1.0 \mathrm{M} \mathrm{C}_{2} \mathrm{H}_{5} \mathrm{OH}$ & $50 \mathrm{mV} \cdot \mathrm{s}^{-1}$ & 2.92 & {$[17]$} \\
\hline $\mathrm{Pd}_{4} \mathrm{Au}_{1}-\mathrm{P} / \mathrm{CNT}$ & $1.0 \mathrm{M} \mathrm{KOH}+1.0 \mathrm{M} \mathrm{C}_{2} \mathrm{H}_{5} \mathrm{OH}$ & $50 \mathrm{mV} \cdot \mathrm{s}^{-1}$ & 2.30 & {$[18]$} \\
\hline $\mathrm{Pd} @ \mathrm{CoP} \mathrm{NSs} / \mathrm{CFC}$ & $1.0 \mathrm{M} \mathrm{KOH}+1.0 \mathrm{M} \mathrm{C}_{2} \mathrm{H}_{5} \mathrm{OH}$ & $50 \mathrm{mV} \cdot \mathrm{s}^{-1}$ & 1.41 & [19] \\
\hline $\mathrm{Pd} / \mathrm{BN}-\mathrm{GNRs}$ & $1.0 \mathrm{M} \mathrm{NaOH}+1.0 \mathrm{M} \mathrm{C}_{2} \mathrm{H}_{5} \mathrm{OH}$ & $50 \mathrm{mV} \cdot \mathrm{s}^{-1}$ & 2.16 & [20] \\
\hline $\mathrm{PdCu}_{2} \mathrm{NCs}$ & $1.0 \mathrm{M} \mathrm{KOH}+1.0 \mathrm{M} \mathrm{C}_{2} \mathrm{H}_{5} \mathrm{OH}$ & $50 \mathrm{mV} \cdot \mathrm{s}^{-1}$ & 1.63 & [21] \\
\hline PdCo NTAs/CFC & $1.0 \mathrm{M} \mathrm{KOH}+1.0 \mathrm{M} \mathrm{C}_{2} \mathrm{H}_{5} \mathrm{OH}$ & $50 \mathrm{mV} \cdot \mathrm{s}^{-1}$ & 1.50 & {$[22]$} \\
\hline $\mathrm{Fe}-\mathrm{Pd}-\mathrm{Fe}_{2} \mathrm{O}_{3} / \mathrm{MWNTs}$ & $1.0 \mathrm{M} \mathrm{KOH}+1.0 \mathrm{M} \mathrm{C}_{2} \mathrm{H}_{5} \mathrm{OH}$ & $50 \mathrm{mV} \cdot \mathrm{s}^{-1}$ & 1.19 & [23] \\
\hline $\mathrm{Pd}_{7} / \mathrm{Ru}_{1} \mathrm{NDs}$ & $1.0 \mathrm{M} \mathrm{KOH}+1.0 \mathrm{M} \mathrm{C}_{2} \mathrm{H}_{5} \mathrm{OH}$ & $50 \mathrm{mV} \cdot \mathrm{s}^{-1}$ & 1.15 & [24] \\
\hline
\end{tabular}


Table S5 Composition data of $\mathrm{Au} @ \mathrm{O}-\mathrm{Pd}_{1} \mathrm{Cu} \mathrm{CNCs}, \mathrm{Au} @ \mathrm{D}-\mathrm{Pd}_{1} \mathrm{Cu}$ NCs and D-Pd $\mathrm{P}_{1} \mathrm{Cu}$ NCs after ADT tests detected by ICP-AES.

\begin{tabular}{|c|c|c|c|c|c|c|}
\hline Catalyst & $\begin{array}{c}\mathrm{Cu} \\
/ \mu \mathrm{g} \mathrm{mL} \mathbf{L}^{-1} \\
\end{array}$ & $\begin{array}{c}\text { Pd } \\
/ \mu \mathrm{g} \mathrm{mL} \mathbf{~}^{-1} \\
\end{array}$ & $\begin{array}{c}\mathrm{Au} \\
/ \mu \mathrm{g} \mathrm{mL} \mathbf{~}^{-1} \\
\end{array}$ & $\begin{array}{l}\text { Cu : Pd : Au } \\
\text { / at : at : at }\end{array}$ & $\begin{array}{c}\mathrm{Cu} / \mathrm{Pd} \\
/ \mathrm{mol} / \mathrm{mol} \\
\end{array}$ & $\begin{array}{c}\text { Pd } \\
/ \text { wt } \% \\
\end{array}$ \\
\hline$\underset{\mathrm{CNCs}}{\mathrm{Au} @ \mathrm{O}-\mathrm{Pd}_{1} \mathrm{Cu}}$ & 23.8 & 40.4 & 35.8 & $0.99: 1: 0.48$ & 0.99 & 40.4 \\
\hline $\mathrm{Au} @ \mathrm{D}-\mathrm{Pd}_{1} \mathrm{Cu} \mathrm{NCs}$ & 19.2 & 35.7 & 45.1 & $0.90: 1: 0.68$ & 0.90 & 35.7 \\
\hline D-Pd ${ }_{1} \mathrm{Cu}$ NCs & 44.9 & 55.1 & - & - & 1.37 & 55.1 \\
\hline
\end{tabular}




\section{References}

[1] Zhang, G. R.; Wu, J.; Xu, B. Q. Syntheses of Sub-30nm Au@ Pd Concave Nanocubes and Pt-On(Au@Pd) Trimetallic Nanostructures as Highly Efficient Catalysts for Ethanol Oxidation. J. Phy. Chem. C 2012, 116, 20839-20847.

[2] Zhang, G.; Yang, Z.; Zhang, W.; Wang, Y. Nanosized Mo-doped $\mathrm{CeO}_{2}$ Enhances the Electrocatalytic Properties of the Pt Anode Catalyst in Direct Methanol Fuel Cells. J. Mater. Chem. A 2017, 5, 1481-1487.

[3] Cong, Y.; McCrum, I. T.; Gao, X.; Lv, Y.; Miao, S.; Shao, Z.; Yi, B.; Yu, H.; Janik, M. J.; Song, Y. Uniform $\operatorname{Pd}_{0.33} \operatorname{Ir}_{0.67}$ Nanoparticles Supported on Nitrogen-Doped Carbon with Remarkable Activity Toward the Alkaline Hydrogen Oxidation Reaction. J. Mater. Chem. A 2019, 7, 3161-3169.

[4] Blochl, P. E. Projector Augmented-Wave Method. Phys. Rev. B 1994, 50, 17953-17979.

[5] Kresse, G.; Furthmüller, J. Efficient Iterative Schemes for Ab Initio Total-Energy Calculations using a Plane-Wave Basis Set. Phys. Rev. B 1996, 54, 11169-11186.

[6] Perdew, J.; Burke, K.; Ernzerhof, M. Generalized Gradient Approximation Made Simple. Phys. Rev. Lett. 1996, 77, 3865-3868.

[7] Methfessel, M.; Paxton, A. High-Precision Sampling for Brillouin-Zone Integration in Metals. Phys. Rev. B 1989, 40, 3616-3621.

[8] Sha, Y.; Yu, T. H.; Merinov, B. V.; Goddard, W. A. DFT Prediction of Oxygen Reduction Reaction on Palladium-Copper Alloy Surfaces. ACS Catal. 2014, 4, 1189-1197.

[9] McQuarrie, D. A.; Simon, J. D. Molecular Thermodynamics, University Science Books, 1999.

[10] Stull, D. R.; Prophet, H. JANAF thermochemical tables, National Standard Reference Data System, 1971. 
[11] Mccrum, I. T.; Janik, M. J. pH and Alkali Cation Effects on the Pt Cyclic Voltammogram Explained using Density Functional Theory. J. Phys. Chem. C, 2016, 120, 457-471.

[12] Chen, L.; Lu, L.; Zhu, H.; Chen, Y.; Huang, Y.; Li, Y.; Wang, L. Improved Ethanol Electrooxidation Performance by Shortening Pd-Ni Active Site Distance In Pd-Ni-P Nanocatalysts. Nat. Commun. 2017, 8, 14136.

[13] Wu, T; Fan, J.; Li, Q.; Shi, P.; Xu, Q.; Min, Y. Palladium Nanoparticles Anchored on Anatase Titanium Dioxide-Black Phosphorus Hybrids with Heterointerfaces: Highly Electroactive and Durable Catalysts for Ethanol Electrooxidation. Adv. Energy Mater. 2018, 8, 1701799.

[14] Cai, B.; Wen, D.; Liu, W.; Herrmann, A. K.; Benad, A.; Eychmüller, A. Function-Led Design of Aerogels: Self-Assembly of Alloyed PdNi Hollow Nanospheres for Efficient Electrocatalysis. Angew. Chem. Int. Edit. 2015, 54, 13101-13105.

[15] Zhu, C.; Shi, Q.; Fu, S.; Song, J.; Xia, H.; Du, D.; Lin, Y. Efficient Synthesis of MCu (M = Pd, $\mathrm{Pt}$, and $\mathrm{Au}$ ) Aerogels with Accelerated Gelation Kinetics and Their High Electrocatalytic Activity. Adv. Mater. 2016, 28, 8779-8783.

[16] Lv, H.; Sun, L.; Chen, X.; Xu, D.; Liu, B. One-Step Fabrication of Trimetallic Core-Shell Au@PdAuCu Mesoporous Nanospheres for Ethanol Electrooxidation. Green Chem. 2019, 21, 20432051.

[17] Chen, Y.; Fan, Z.; Luo, Z.; Liu, X.; Lai, Z.; Li, B.; Zong, Y.; Gu, L.; Zhang, H. High-Yield Synthesis of Crystal-Phase-Heterostructured 4H/fcc Au@Pd Core-Shell Nanorods for Electrocatalytic Ethanol Oxidation. Adv. Mater. 2017, 29, 1701331.

[18] Yang, H.; Yu, Z.; Li, S.; Zhang, Q.; Jin, J.; Ma, J. Ultrafine Palladium-Gold-Phosphorus Ternary Alloyed Nanoparticles Anchored on Ionic Liquids-Noncovalently Functionalized Carbon Nanotubes with Excellent Electrocatalytic Property for Ethanol Oxidation Reaction in Alkaline Media. J. Catal. 
2017, 353, 256-264.

[19] Ye, S. H.; Feng, J. X.; Li, G. R. Pd Nanoparticle/CoP Nanosheet Hybrids: Highly Electroactive and Durable Catalysts for Ethanol Electrooxidation. ACS Catal. 2016, 6, 7962-7969.

[20] Liu, Q.; Fan, J.; Min, Y.; Wu, T.; Lin, Y.; Xu, Q. B, N-Codoped Graphene Nanoribbons Supported Pd Nanoparticles for Ethanol Electrooxidation Enhancement. J. Mater. Chem. A 2016, 4, 4929-4933.

[21] Hu, C.; Zhai, X.; Zhao, Y.; Bian, K.; Zhang, J.; Qu, L.; Zhang, H.; Luo, H., Small-sized PdCu Nanocapsules on 3D Graphene for High-performance Ethanol Oxidation. Nanoscale 2014, 6, 2768-75. [22] Wang, A. L.; He, X. J.; Lu, X. F.; Xu, H.; Tong, Y. X.; Li, G. R. Palladium-Cobalt Nanotube Arrays Supported on Carbon Fiber Cloth as High-Performance Flexible Electrocatalysts for Ethanol Oxidation. Angew. Chem. Int. Ed. 2015, 54, 3669-3673.

[23] Wang, Y.; He, Q.; Guo, J.; Wang, J.; Luo, Z.; Shen, T. D.; Ding, K.; Khasanov, A.; Wei, S.; Guo, Z. Ultrafine FePd Nanoalloys Decorated Multiwalled Cabon Nanotubes Toward Enhanced Ethanol Oxidation Reaction. ACS Appl. Mater. Int. 2015, 7, 23920-23931.

[24] Zhang, K.; Bin, D.; Yang, B.; Wang, C.; Ren, F.; Du, Y. Ru-Assisted Synthesis of Pd/Ru Nanodendrites with High Activity for Ethanol Electrooxidation. Nanoscale 2015, 7, 12445-12451. 